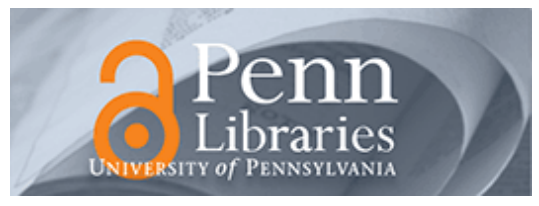

University of Pennsylvania

ScholarlyCommons

Finance Papers

Wharton Faculty Research

$12-2014$

\title{
The Euro and Corporate Financing Before the Crisis
}

Arturo Bris

Yrjo Koskinen

University of Pennsylvania

Mattias Nilsson

Follow this and additional works at: https://repository.upenn.edu/fnce_papers

Part of the Finance Commons, and the Finance and Financial Management Commons

\section{Recommended Citation}

Bris, A., Koskinen, Y., \& Nilsson, M. (2014). The Euro and Corporate Financing Before the Crisis. Journal of Financial Economics, 114 (3), 554-575. http://dx.doi.org/10.1016/j.jfineco.2014.08.003

This paper is posted at ScholarlyCommons. https://repository.upenn.edu/fnce_papers/252

For more information, please contact repository@pobox.upenn.edu. 


\title{
The Euro and Corporate Financing Before the Crisis
}

\author{
Abstract \\ We study the financing policies of European public corporations prior to the euro crisis. Using data from \\ 11 euro countries and a control group of five other European countries over 1991-2006, we show that \\ nonfinancial firms from euro countries with previously weak currencies considerably increased their debt \\ financing after the introduction of the euro. The results are stronger for large firms, firms dependent on \\ external financing, and for the latter part of the post-euro time period. Overall, the results support the \\ hypothesis that the supply of capital increased following the introduction of the euro.

\section{Disciplines} \\ Finance | Finance and Financial Management
}




\title{
The Euro and Corporate Financing before the Crisis*
}

\author{
Arturo Bris \\ IMD and ECGI
}

\author{
Yrjö Koskinen \\ Boston University
}

\author{
Mattias Nilsson \\ University of Colorado \\ at Boulder
}

March 11, 2014

Accepted for publication at the Journal of Financial Economics

\begin{abstract}
We study the financing policies of European public corporations prior to the euro crisis. Using data from eleven euro countries and a control group of five other European countries over 1991-2006, we show that non-financial firms from euro countries with previously weak currencies considerably increased their debt financing after the introduction of the euro. The results are stronger for large firms, firms dependent on external financing and for the latter part of the post-euro time period. Overall, the results support the hypothesis that the supply of capital increased following the introduction of the euro.
\end{abstract}

JEL classification: F33, F36, G32

Keywords: euro, financial integration, external financing, debt financing, supply of capital, financial dependence.

\footnotetext{
*The authors would like thank Henrik Cronqvist, Eric Hughson, Matthias Kahl, Pedro Matos, Raghu Rau, Josef Zechner, Toni Whited, François Derrien, Buhui Qiu, and seminar participants at Bank of Finland, Claremont McKenna College, Hanken/Helsinki School Economics, Boston University, and NHH Bergen for helpful comments. We are also grateful for comments from participants at European Winter Finance Summit in Hermagor, Austria, conference on Financial Intermediation and the Real Economy in Paris, and EFA in Cambridge. An earlier version of the paper was circulated under the title "The Euro and Corporate Financing." The project was initiated when Koskinen was visiting the Bank of Finland, he is grateful for the Bank's hospitality. All remaining errors are our responsibility. Contact information: Arturo Bris, arturo.bris@imd.ch ; Yrjö Koskinen, yrjo@bu.edu ; Mattias Nilsson, mattias.nilsson@colorado.edu
} 


\section{Introduction}

In 2009 European Union celebrated the $10^{\text {th }}$ anniversary of the introduction of the euro as its common currency. In a report published in 2008 the European Commission claimed that the first decade of the Economic and Monetary Union was a "resounding success" (European Commission, 2008). Those words turned out to be premature. Soon after the celebrations were over, the euro area was tossed into a severe crisis from which it has yet to fully emerge from.

The extant macroeconomics literature has identified a private sector credit boom and related current account deficits as major causes for the crisis (Lane, 2012). This paper aims to participate in this debate on the roots of the crisis by providing firm-level evidence on corporate financing choices before the onset of the crisis. In particular, we examine if the euro has led to an increase in the use of debt financing for companies hailing from the euro area compared to other European companies.

Previous research by Bris, Koskinen, and Nilsson (2006, 2009) show that the introduction of the euro resulted in increases in corporate valuations and investments for euro area firms compared to other European firms. Bris et al. attribute these findings mainly to a decrease in cost of equity and debt capital. As a result of decreased cost of capital, the demand for external financing is expected to have increased in the euro area compared to other comparable European countries. The supply of capital may have also increased in the euro area. For example, euro area financial markets have become less segmented since the introduction of the euro, as manifested by the increase in cross-border portfolio investments, in particular for bonds (see, e.g., De Santis and Gerard, 2006; Lane, 2006; Lane and Milesi-Ferretti, 2007). Thus firms have become less dependent on domestic investors when raising external financing. In addition, the implementation of the ambitious legislation known as the Financial Services Action Plan (FSAP) during the first half of 2000's has made it easier to provide financial services throughout the European Union and thus could have facilitated cross-border financial intermediation (Kalemli-Ozcan, Papaioannou, and Peydro, 2010). The euro countries may have been particularly well positioned to take advantage of this regulatory integration by already sharing a common currency. 
We provide evidence that the introduction of the euro has led to an increase in external financing, especially debt financing, for firms hailing from euro countries. Based on our sample of public firms, non-financial firms are likely to have significantly contributed towards current account deficits among the crisis countries by borrowing more. Our results are stronger for firms from those euro countries that previously had weak currencies, consistent with the idea that increased external financing is due to higher demand for financing. However, there is clear evidence that increased supply has also been a major contributing factor. Large firms, who have better access to foreign banks and investors, have increased their debt financing more, despite of the fact that previous research show that their valuations increased less than the valuations for smaller firms [see Bris, Koskinen, and Nilsson (2009) for relative valuations]. Moreover, firms in industries that are more dependent on external financing have increased their debt financing more. Finally, results are stronger during the second half of our time period, partially due to the implementation of FSAP. These findings support the idea that improved supply of capital has led to increased use of external financing among the euro countries.

We estimate regressions where the change in total external financing, the change in debt, or the change in external equity, all normalized by lagged assets, are the dependent variables. As explanatory variables we use measures of size, profitability, collateral, a proxy for industry level growth opportunities (corresponding U.S. industry Tobin's Q), together with dummies indicating firms in the euro area for the time the common currency has been in use. Our sample consists of 2,486 firms from 16 European countries in the period 1991-2006. In particular, we use corporate-level data from the eleven original countries that adopted the euro in 1999, and as our control sample we use the three EU countries that did not adopt the euro (Denmark, Sweden, and the U.K) as well as Norway and Switzerland. Using a control sample allows us to compute differences-in-differences estimators to measure the impact of the euro both cross-sectionally and in the time-series domain.

We show that the introduction of the euro has on average lead to a $1.9 \%$ annual increase in external financing relative to assets for companies from the euro area compared to companies from our control countries. When we split the sample of euro firms between firms in weak euro countries (i.e., 
countries that suffered a currency crisis in the years before the introduction of the euro) and strong euro countries, we find that for the weak euro countries the annual increase in external financing is $4.2 \%$ of assets, composed of 2.6\% increase in debt financing and 1.4\% increase in external equity financing. For strong euro countries there is no increase in external financing, but equity issuance increases by $0.8 \%$ annually.

We also estimate individual country results, using firms from the U.K. as the benchmark. Among the individual euro countries, the results are the strongest for firms from the now troubled countries of Italy, Portugal, and Spain, as well as for firms from the currently financially more solid northern euro countries of France, Netherlands, and Finland. ${ }^{1}$ Among the non-euro countries, Denmark stands out as the only country in which firms on average significantly increase their external financing, in particular debt financing, after 1999.

Among industries, the results are the strongest for basic industries (agriculture, mining, and construction) and for service industries among the weak euro countries. Since construction is part of basic industries, the results for that industry are not surprising in view of the real estate boom in some euro countries. However, we should bear in mind that our results are relative to the control group, which is dominated by the firms from the U.K., and that the U.K. also experienced a real estate boom.

The results showing that firms from weak euro countries have on average raised more external financing than firms from strong euro countries is consistent with the explanation that demand for financing has increased, since Bris, Koskinen, and Nilsson (2006, 2009) show that the weak euro firms experienced higher increases in $\mathrm{Q}$ and investment levels after the introduction of the euro. In order to examine if supply of financing is also a major contributing factor for the increase in external financing in the euro area, we classify industries to be dependent on external financing by measuring the fraction of investments financed by external finance in corresponding industries in the U.S. between 1991 and 1997 (following the procedure of Rajan and Zingales, 1998). We then show that industries that are dependent

\footnotetext{
${ }^{1}$ Note that Finland is classified as a weak euro-country in our analysis as it was hit by a significant currency crisis in the early 1990s
} 
on external financing have significantly increased their debt and equity financing compared to the control group after the introduction of the euro. The result holds for all euro firms, but it is much stronger for firms from weak euro countries (annual increase is 3.9\% of assets in debt financing and 1.6\% in equity financing). Interestingly, the results for debt financing are also stronger for large firms (defined as having above sample median average sales in the pre-euro period). For example, large firms from weak euro countries have increased their debt financing by 3.2\% of assets annually, whereas the increase for smaller firms is $2.2 \%$. One possible explanation is that larger firms have the most to gain from financial market integration, as international investors and banks have a preference for larger, more well-established firms. Consistent with this view, Gozzi, Levine, and Schmukler (2010) show that large firms dominate financing from international capital markets.

We further show that external financing has increased more in the 2003-2006 time period than in the 1999-2002 period, even though a significant increase in valuations occurred already in the earlier time-period (Bris, Koskinen, and Nilsson, 2009). If demand for financing were the sole factor contributing for greater use for external financing, firms should have raised more financing already in 1999-2002. One mechanism that has contributed to stronger results in the latter half of our sample is the adoption of the Financial Services Action Plan (FSAP). FSAP is an EU-wide legislative program whose purpose is to facilitate cross-border provision of financial services. Our result for euro countries is partially explained by including an index that reflects when the actual legislation was implemented in different member countries.

Next, we analyze the use of external financing by looking at the effect of the euro on changes in non-cash assets, changes in cash holdings, changes in dividend payments, and changes in total payouts. Consistent with the corporate investment results in Bris, Koskinen, and Nilsson (2006), we find that euro firms have significantly increased their non-cash assets relative to other firms. Interestingly, cash holdings, dividends or total payouts have not grown compared to our control group. Firms that belong to industries that are more dependent on external financing have experienced higher growth in non-cash assets. Better access to financing has thus had real consequences. Consistent with the external financing 
results, the growth in non-cash assets has been faster after 2002. Even though valuations increased immediately when euro was introduced, it seems to have taken some time before the institutional framework was ready to support increased firm growth.

Next section reviews the literature. Section 3 describes the data sources, and the variables used in the paper. Section 4 discusses the methods and main results. Section 5 studies how dependence on external financing affects financing. Section 6 provides evidence on the importance of deepening financial integration and regulatory harmonization over time. Section 7 focuses on asset growth. Finally, Section 8 concludes.

\section{Related literature}

The extant macroeconomics literature on the euro crisis has started to emphasize private sector credit booms and related current account deficits as perhaps the most important explanatory factors for the euro crisis. For example, Lane (2012) documents the dramatic increase in private sector credit and current account deficits that occurred for those euro countries that are now engulfed in severe recessions. Lane (2013) shows that capital flows in the euro area were dominated by debt and that the increase in net foreign debt is positively correlated with growth in private credit for euro countries before the crisis. We complement these aggregate results by providing firm-level evidence for significant increases in external financing, in particular debt financing, in the euro area. Consistent with the macroeconomics literature, our results are stronger for firms hailing from the crisis countries. ${ }^{2}$

Some of our results are consistent with the view that the cost of capital has decreased in the euro area, leading to a surge in that demand for external financing. There is strong evidence for the decline in cost of capital in the euro area. Bartram and Karolyi (2006) show that systematic risk has been significantly reduced due to the introduction of the euro. Hardouvelis, Malliaropulos, and Priestley (2007) find evidence that the cost of equity has decreased in the euro area since the introduction of the euro, and that

\footnotetext{
${ }^{2}$ For a pre-crisis overview of the macroeconomic effects of the euro, see Beetsma and Giuliodori (2010).
} 
there is no similar reduction in cost of capital for those EU countries that that chose not to adopt the euro as their currency. Bris, Koskinen, and Nilsson (2009) find evidence for cost of equity reduction using Tobin’s Q-ratios: valuations measured using Q-rations have increased after the introduction of the euro, especially for countries that devalued their currencies during the EMS-crisis of 1992-93. Hassan (2013) shows that the cost of equity has decreased in the euro area for the non-tradable sector and that real interest rates have declined, because bonds denominated in euro provide better insurance against consumption shocks than bonds issued in the legacy currencies would have provided. Based on this literature, we would expect firms in the euro area on increase their external financing, and this is indeed what we find. ${ }^{3}$

Some of our results cannot be explained by a decrease in the cost of capital. For example large firms have increased their external financing more despite the fact that their valuation have increased less than the valuations for smaller firms. One reason for this is that large firms are better positioned to benefit from financial integration. There is plenty of evidence that financial markets have become less segmented and more integrated in the euro area. For example, Hardouvelis, Malliaropulos, and Priestley (2006) show that excess stock returns in the euro area have become more sensitive to common euro risk at the expense of country-specific risks. Cappiello, Kadareja, and Manganelli (2010) show that co-movements between European stock market returns have increased since 1999, which implies increased stock market integration. Corporate bond markets have also become more integrated and credit spreads have converged across the euro area. Baele, Ferrando, Hördahl, Krylova, and Monnet (2004) show that since the adoption of the euro, the impact of country-factors in explaining credit spreads has become economically small and that credit spreads are more influenced by fundamental factors like ratings and maturity.

Transactions costs for buying euro area assets have declined significantly since the introduction of the euro. Coeurdacier and Martin (2009) provide evidence that the costs for buying euro area bonds and stocks have decreased significantly. Lower transactions costs, elimination of intra euro area

${ }^{3}$ Contrary to the prevailing evidence, Bekaert, Harvey, Lundblad, and Siegel (2013) find no evidence for a euro effect. Bekaert et al. (2013) study valuation differentials and they show that there is a strong European Union effect: bilateral valuation differentials are significantly lower for EU members than for non-members. 
exchange rate risk, and currency matching rules for assets and liabilities becoming irrelevant within euro area, have resulted in a dramatic increase in cross-border portfolio investments between euro countries. The increase is portfolio investments is more pronounced for bonds (see, e.g., Lane, 2006; De Santis and Gerard, 2006), but cross-border holdings within euro area have also increased significantly for equities (see, e.g., De Santis and Gerard, 2006; Lane and Milesi-Ferretti, 2007). Finally, Kalemli-Ozcan, Papaioannou, and Peydro (2010) show that bilateral bank holdings have also increased between euro countries by $25-30 \%$ compared to other EU members.

Increased cross-border portfolio investments imply that firms in the euro area are less dependent on domestic markets for their financing needs and in particular that firms that were previously financially constrained due to underdeveloped domestic financial markets would be expected to increase their external financing more than other firms. Consistent with this, we find that firms from industries that are more dependent on external financing have increased their debt financing more than firms that are less dependent on external financing.

We are not the first ones to emphasize that changes supply of capital matter for firms' financing choices. Faulkender and Petersen (2006) compare firms that have bond ratings - and thus access to bond markets - to firms that do not. They show that firms with bond ratings have $35 \%$ more debt in their capital structures. Like Faulkender and Petersen (2006) we show that even large corporations may face financing constraints and that access to credit markets is a significant determinant in firms' financing choices. Papers by Leary (2009), Sufi (2009), and Lemmon and Roberts (2010) identify exogenous shocks that have led to a change in the supply of capital. Leary (2009) finds that the emergence of market for certificate of deposits in 1961 and the resulting expansion in bank credit led to increased leverage for firms. Sufi (2009) shows that the introduction of syndicated loan ratings in 1995 led to increased borrowing by firms that obtained a rating. Lemmon and Roberts (2010) study the collapse of Drexel Burnham Lambert and the resulting decrease in high-yield bond financing and show that this led to a decrease in financing and investments for those firms that were using high-yield debt financing. The introduction of the euro is also an exogenous event, implemented partially for political reasons [as argued 
by Bris, Koskinen, and Nilsson (2009)]. However, since the euro is likely to have affected both the demand for and supply for capital, its introduction alone cannot provide direct evidence that an increase in supply of capital is a major cause for the observed increase in external financing. For that purpose, we utilize the implementation of the Financial Services Action Plan (FSAP) that aims to facilitate the provision of cross-border financial services within the EU. Like Kalemli-Ozcan, Papaioannou, and Peydro (2010), we use the differences in the timing of implementation for FSAP across EU member states and show that the implementation of FSAP partially explains the increase in external financing. Thus, like Leary (2009), Sufi (2009), and Lemmon and Roberts (2010), we utilize an exogenous shock to highlight the importance of supply of capital in firms’ financing choices.

\section{Data description}

\subsection{Sample}

The sample of firms used in this study is gathered from Worldscope and covers the period 19912006. The sample includes firms from the eleven countries that first adopted the euro at its introduction in January 1999: Austria, Belgium, Finland, France, Germany, Ireland, Italy, Luxemburg, the Netherlands, Portugal, and Spain. Our comparison sample of firms is drawn from three EU, non-euro countries (Denmark, Sweden, and the U.K.) as well as from Norway and Switzerland. We consider these five non-euro countries to constitute appropriate benchmark countries for an analysis of the impact of the euro on firms' financing activities. Denmark, Sweden, and the U.K. all opted out from joining the Economic and Monetary Union (EMU) ${ }^{4}$ at the outset. Norway and Switzerland obviously cannot join EMU as non-EU countries, but at the same time they are tightly integrated with the EU in many areas

\footnotetext{
${ }^{4}$ To be more precise, the third phase of the EMU, which deals with the adoption of the euro. The first and second phases of the EMU dealt with free movement of capital and monetary policy coordination between independent central banks.
} 
relevant to business thanks to geographical proximity and follow EU regulations because of the European Economic Area - agreement. ${ }^{5}$

As is standard in corporate finance research, we exclude financial firms (SIC codes 6000-6999). We also exclude firm-year observations missing any data in Worldscope needed to construct our outcome variables or full set of firm-level control variables. Furthermore, we exclude firm-year observations with zero sales or negative book values of equity. Finally we require that the remaining firms appear in the sample for at least one year during 1991-1997 and at least one year during 1999-2006. This last requirement ensures that firms exist both before and after the introduction of the euro in January 1999. Firms that appear only in 1998 in the pre-euro period are excluded because by then it was clear that the euro would come to fruition, and that fact could have been a factor behind firms' decision to go public at the time. Because we do not require that the firms exist for the whole sample period of 1991-2006, we end up with an unbalanced panel of firms.

Our final sample consists of 2,486 firms (29,332 firm-year observations): 1,348 firms (16,098 firm-year observations) from the euro countries and 1,138 firms (13,834 firm-year observations) from the non-euro countries. Germany and France together contribute more than half of the firms to the euro sample (742 firms; 8,753 firm-year observations); whereas the U.K. dominates the non-euro sample with 696 firms (8,523 firm-year observations). Although firms in Germany, France and the U.K. make up a majority of the sample, our results are robust to excluding all of these observations.

\subsection{Variables}

Appendix A lists the full technical definitions of the variables used in this study and Appendix B presents summary statistics for the whole sample.

\footnotetext{
${ }^{5}$ Greece was a non-euro, EU member at the time of the initial introduction of the euro and was actively looking to adopt the euro. However, because Greece did not fulfill the convergence criteria of the Maastricht treaty, the country did not officially adopt the euro until January 2001. We exclude Greece from the main analysis because it is difficult to classify Greece as either a non-euro or euro country in 1999 and 2000. We also exclude the new euro-members Slovenia, Cyprus, Malta, Slovakia, Estonia, and Latvia - for the same reason and also for the reason that for these countries there are very few observations available.
} 
To capture firms financing activities we construct three different variables: Net Debt Issues, Net Equity Issues, and Net External Finance. Net Debt Issues is defined as the net change in the book value of total financial debt over a given year divided by the lagged book value of assets. Similarly, Net Equity Issues is defined as the net change in external equity divided by the lagged book value of assets. We calculate the net change in external equity any given year as reported proceeds from sales of common and preferred stock minus purchases and retirements of common and preferred stock as stated in a firms' cash flow statement. When the data on proceeds from equity issues or repurchases are missing (4,461 firmyear observations), we instead calculate the variable as the change in the book value of common and preferred stock minus the change in retained earnings. This latter definition is clearly an approximation of net equity issued, but our results are qualitatively the same if we constrain our sample to those firm-years with complete information in their cash flow statement on equity issues and repurchases. Finally, we define Net External Finance as the sum of Net Debt Issues and Net Equity Issues. Because the net debt and equity issues variables are expressed as fractions of the past period's assets, Net External Finance captures the net contribution of all external financing activities to asset growth. We winsorize the financing variables at the 1st and 99th percentiles to reduce the influence of extremely fast growing or shrinking firms (mainly caused by M\&As and divestitures). Appendix B show that over the entire time period we study, non-euro firms on average raise more external capital per year than euro firms (4.2\% of previous year's assets vs. 3.7\%). This larger external financing activity appears to be due to larger equity issues.

Regarding other firm characteristics used in this study, Appendix B shows that euro firms on average have larger sales, lower growth opportunities (as measured by median industry Q for corresponding US firms), less collateral value, and somewhat greater profitability (EBITDA/assets).

Turning to the country characteristics we use as control variables, Appendix B shows that euro countries on average grew faster during the whole sample period than non-euro countries, although this is mainly due to Ireland. It is also notable that euro countries had on average a much larger bond term spread (41 basis points larger). 


\section{The euro and external financing: main results}

\subsection{Empirical methodology}

To analyze the impact of the formation of the euro on firms' external financing activities, we employ a standard difference-in-differences methodology. That is, we estimate the impact of the euro by comparing differences in financing activities before and after the euro for the firms in the euro countries and compare these differences with the comparable differences for a sample of firms from non-euro countries. More formally, for our sample in which firm $i$ is observed annually at year $t$, we estimate the effect of the euro on financing variable $y$ in OLS regressions of the following kind:

$$
y_{i t}=\alpha_{i}+\theta_{t}+\beta X_{i t}+\delta E U R O_{i t}+\varepsilon_{i t}
$$

where $\alpha_{i}$ is the fixed firm effect for firm $i, \theta_{t}$ is the fixed time effect for year $t, X_{i t}$ is a vector of timevarying control variables, $E U R O_{i t}$ is a dummy variable indicating whether or not the euro was adopted by firm $i$ 's country at time $t$, and $\varepsilon_{i t}$ is the residual. To control for serial dependence within a country, we estimate standard errors robust to clustering at the country level.

The fixed firm effects control for any unobserved constant factors that could influence firms' financing choices (this includes constant industry and country factors). The fixed time effects control for time trends common for both euro and non-euro firms. Because of the inclusion of these time dummies, the coefficient $\delta$ is the difference-in-differences estimator of the impact of the euro.

The dummy variable EURO in equation (1) is equal to 1 if the year is 1999 or later and the firm belongs to a country that adopted the euro, otherwise it is 0 . As an alternative specification, we replace EURO with two dummies indicating firms in strong and weak euro countries, respectively, in the posteuro period. The weak euro countries are the euro countries that had to abandon their pegged exchange rates or devalue their currencies during the ERM crisis of 1992-93. We make the distinction between strong and weak euro countries since Bris, Koskinen, and Nilsson (2006, 2009) show that the weak euro firms experienced higher increases in valuations and investment levels after the introduction of the euro. 
They attributed these results to a removal of devaluation risk and resulting decrease in the cost of capital. An alternative justification for classifying euro countries into weak and strong is that the classification could be a proxy for international financing constraints. Caballero and Krishnamurthy (2001) argue that firms face two kinds of collateral constraints in borrowing: domestic and international constraints. Because of a history of devaluations, firms in weak euro countries may have faced more stringent international financing constraints than firms in strong euro countries.

One important concern regarding the validity of the difference-in-differences estimation outlined above is the parallel trends assumption. If the control sample of non-euro firms has a different underlying trend regarding financing activities than the euro firms prior to the introduction of the euro, we may estimate a significant difference-in-differences effect that is not caused by the introduction of the euro, but is rather just an artifact of already diverging trends in the dependent variables between the two groups of firms. ${ }^{6}$ We perform the following informal test of the parallel trends assumption: First we define the two years right before the introduction of the euro (i.e., years 1997 and 1998) as the Late Convergence Period. We then estimate Eq. (1) above for the time period 1991-1998 only, where the EURO dummies are replaced with similar dummies indicating that a firm is a euro firm and the time is the Late Convergence Period. Appendix C displays the results from this exercise. The results show that there is no significant difference in financing activities between euro firms and non-euro firms during the Late Convergence Period relative to the prior years (1991-1996). These results are consistent with the parallel trends assumption holding in our data.

\subsection{Univariate results}

Before turning to our regression analysis, we first present some univariate difference-indifferences results in Table 1. For each of our three financing variables, we calculate an average for the pre-euro period and the post-euro period separately. We then calculate the difference between the posteuro and the pre-euro averages, which gives us a firm specific difference in means. The pre-and post euro

\footnotetext{
${ }^{6}$ See Roberts and Whited (2012) for a more in-depth discussion of the importance of the parallel trends assumption for the validity of difference-in-differences estimators.
} 
individual firm averages as well as within-firm differences are then averaged across all firms in the euro countries and non-euro countries, respectively.

Panel A of Table 1 show that euro firms on average decrease their yearly net external financing, expressed as a fraction of last year's assets, with -0.002 following the introduction of the euro, but the decrease is not statistically significant. Non-euro firms' change in Net External Finance is -0.030 (significant at the 1\%-level). The difference-in-differences between euro and non-euro firms is strongly statistically significant (at the 1\%-level) according to t-tests, implying that non-euro firms decrease their external financing more. Looking at strong versus weak euro firms, we see that strong euro firms on average decrease their yearly external financing by -0.010 (significant at the $1 \%$-level) whereas weak euro firms increase theirs by 0.018 (significant at the 1\%-level). However, the difference-in-differences between strong euro firms and non-euro firms is still significant (at the 1\%-level). The difference-indifferences between weak and strong euro firms is also significant (at the $1 \%$ - level).

Panels B and C show that the patterns for Net Debt Issues and Net Equity Issues. Non-euro firms significantly decrease both debt and equity issues on average, whereas there is an insignificant increase in Net Debt Issues and a significant (at the 5\%-level) decrease in Net Equity Issues for euro firms overall. The difference-in-differences between non-euro and euro firms is significant for both debt and equity issues. For weak vs. strong euro firms, we see that strong euro firms experience an insignificant decrease in their debt issues. By contrast weak euro firms significantly increase their debt issues (an increase of 0.030, significant at the $1 \%$-level). For equity issues there is a significant decrease for strong euro firms, whereas for the weak euro firms the decrease is insignificant. The change for both groups is significantly different from the change for non-euro firms.

Overall, the univariate difference-in-differences evidence suggests that the euro has enabled euro firms to increase their external financing relative to non-euro firms. This seems to be particularly true for weak euro firms, who increase their debt financing also in absolute terms and not just relative to non-euro firms. 


\subsection{Main regression results}

We next estimate the regression outlined in Eq. (1) above. We run two different specifications of the regression model for each of three dependent variables (Net External Finance, Net Debt Issues, and Net Equity Issues), one with one single euro dummy, and one with different euro dummies for strong euro firms and weak euro firms, respectively. As control variables we use five different firm characteristics, all of which are lagged one year relative to our outcome variables: US Industry $Q$, Log(sales), EBITDA/Assets, Collateral/Assets, and a dummy variable indicating whether leverage (expressed as total liabilities/assets) is above 90\% [ I(Leverage $>90 \%)$ ]. US Industry $Q$ is our proxy for a firm's investment opportunities and is the median Q of US firms in the same two-digit SIC code and year. We do not use firms’ individual Q ratios because Bris, Koskinen, and Nilsson (2009) show that they are affected by the introduction of the euro and are therefore endogenous in this setting. $\log ($ sales) is our proxy for firm size and is calculated using sales in real USD. EBITDA/Assets is a measure of a firms operating profitability, and Collateral/Assets is meant to capture the debt capacity of tangible assets. Versions of these four variables have previously been used, for example, by Sufi (2009) to explain the use of external debt financing. We also add $I($ Leverage $>90 \%)$ as control variable based on the idea that firms with extreme leverage ratios have exhausted their debt capacity and are more or less forced to issue equity when they raise external capital. $^{7}$

Finally, we add three country characteristics as control variables: GDP Growth, Term Spread, and Change in USD Exchange rate. GDP Growth (the real GDP growth rate) is included to capture differences in contemporaneous business cycles across countries and Term Spread (the 10-year government bond rate minus the 6-month t-bill rate) is included because it captures expectations of future growth and inflation, which can affect firms current financing decisions. Both of these variables are lagged one year relative to the outcome variables. Change in USD Exchange rate, defined as the percentage change in the domestic currency/USD exchange rate from the end of the previous year to the

\footnotetext{
${ }^{7}$ Our results are robust to the use of other specifications to control for the level of leverage at the beginning of each year, including using the leverage ratio directly.
} 
end of the current year, is included because the firm level accounting variables that form the basis for our outcome variables are measured in USD and we want to make sure that we capture actual firm decisions and not just differences in dollar value fluctuations across currencies.

Table 2 presents the main estimation results. We see that the introduction of the euro has lead to an annual increase in external financing equal to $1.9 \%$ of beginning-of-year assets for companies from the euro area compared to companies from our control countries (significant at the $10 \%$ level) . The annual increase is $1 \%$ for external equity financing (significant at the $1 \%$-level), but there is no significant increase in debt financing. When we split the sample of euro firms between firms in weak-euro and strong euro countries, we find that for the weak euro countries the annual increase in external financing is $4.2 \%$ (significant at the $1 \%$ - level), composed of a $2.6 \%$ increase in debt financing and $1.4 \%$ increase in external equity financing (both effects significant at the 1\%-level). For strong euro countries there is no significant increase in external financing, but equity financing has increased by $0.8 \%$ per year (significant at the 5\%-level. The larger increases in total external financing, as well as the larger increase in debt and equity issues for weak euro firms versus strong euro firms are all statistically significant at the $1 \%$ level.

In Table 2 we classified firms as weak or strong euro firms. The results in that table could be due to the fact that firms from France, Germany, and the U.K. dominate the sample. In order to make sure that a few large countries do not determine the results we present results by individual countries in Table 3. We use the U.K. as the benchmark, so all the results are relative to the U.K. results. The results are what we expect them to be, with some exceptions. Firms from weak euro countries have increased both their debt and equity financing. The results are especially strong for Italy and Spain, where the annual increase for external financing is $4.5 \%$ and $8.2 \%$ of assets, respectively. The increase is due to both debt and equity financing, but the increase in debt financing is the predominant reason. The outlier among the weak euro countries is Ireland, where the net external financing is not showing any increase and debt financing has actually decreased modestly (a decrease of $0.9 \%$ per year). The Irish results are consistent with the findings of Bris, Koskinen, and Nilsson (2009), who show that Ireland didn’t experience any 
increase in corporate valuations after the introduction of the euro. The effects for strong euro countries are generally lower than the effects for weak euro countries. The exception among the strong euro countries is Netherlands, which has experienced an increase in external financing of 3.1\% per year, comparable to increases in weak euro countries like Finland and Portugal. Among the control group only Denmark shows significant increases in debt and equity financing. Denmark is different from all other non-euro countries: it is the only non-euro country in our sample that has maintained a tight currency peg with respect to the euro. Thus it may not be that surprising that Denmark is behaving like a euro country.

In Table 4 we show the external financing results by industry. Some weak euro countries, especially Ireland and Spain, experienced dramatic increases in real estate prices resulting in construction booms. We want to examine to what extent our results can be explained by that. Consistent with the hypothesis that real estate played a significant part in the increase in external financing, basic industries (including construction) experience very high increases in external financing. For weak euro countries the increase is $6.9 \%$ of assets annually (significant at the $10 \%$-level), largely driven by the increase in debt financing (an increase of $6.4 \%$ annually, significant at the 1\%-level). However, services industries show the largest increases for the weak euro countries: 7.9\% increase in external financing, with $5.4 \%$ increase in debt financing annually. In addition, for the weak euro countries, manufacturing (3.5\% increase in external financing) and transportation, communications, and utilities (4.8\% increase in external financing) show strong results. The increase in external financing for manufacturing can be attributed both to debt financing (an increase of $1.9 \%$ annually) and equity financing (1.4\% increase). For transportation, communications, and utilities the increase is solely due to debt financing (an increase of $4.4 \%$ annually). Thus among the weak euro countries, the increases in external financing are widely spread among different industries and not attributable only to basic industries, which construction is a part of.

For strong euro countries the increases in net external financing are largely due to increases in equity financing, with the exception of basic industries, where both debt and equity financing show statistically and economically significant increases. 


\section{External finance dependence and the effect of the euro on financing activities}

To further examine the reasons for the increase in external financing, we follow Rajan and Zingales (1998) and classify industries' level of dependence on external financing by measuring the fraction of capital expenditures financed by external funds in corresponding industries in the U.S. between 1991 and 1997. Rajan and Zingales argue that because the United States have relatively frictionless financial markets, U.S. industries external finance dependence is likely to capture the technological demand for external finance. For our purpose, the U.S. industry external dependence provides us with an external finance dependence measure that is exogenous to the formation of EMU.

Specifically, we first match our sample industries to corresponding U.S. industries based on two digit SIC codes. We then identify all U.S. firms in corresponding industries over the 1991-1997 time period. For each industry-matched U.S. firm, we calculate the individual fraction of capital expenditures financed by external funds as the sum of external financing (= capital expenditures minus net cash flow from operating activities) divided by the sum of capital expenditures over 1991-1997. We then calculate the median external finance dependence by industry and use that as the overall measure of an industry's external finance dependence. Finally we classify an industry (and consequently any firm in this industry) as more external finance dependent if its industry has a higher external finance dependence than the median industry represented in the sample (external finance dependence $=0.211$ ). Remaining industries are consequently labeled as less external finance dependent.

Table 5 replicates our main analysis in Table 2 but splits the sample in two according to external finance dependence. Panel A shows the estimation results for the more external finance dependent subsample and Panel B shows the equivalent results for less external finance dependent subsample. We see that the effect of the euro on external financing activity is much larger in magnitude in more external finance dependent industries. In the more dependent sample, firms in the euro area on average increase Net External Finance by $2.7 \%$ of assets more than non-euro firms following the introduction of the euro (significant at the 1\%-level). In the less dependent sample, there is no increase in overall external 
financing, but net equity issues increase by $0.9 \%$ annually. When we distinguish between strong and weak euro firms, we see that weak euro firms in both subsamples increase their external financing significantly (5.6\% for more dependent firms, 3.3\% for less dependent), but the results are much weaker or even nonexistent for strong euro firms (1.6\% increase for more finance dependent firms, statistically significant at the 10\%-level, and no increase for the less dependent firms). This is consistent with the results in Table 2.

Looking at the results for Net Debt Issues and Net Equity Issues we see that the comparatively larger effect of the euro on total external financing is more due to an increase in debt issues than an increase in equity issues. In the more dependent sample, weak euro firms increase Net Debt Issues with $3.9 \%$ of assets versus an increase of $1.9 \%$ in the less dependent sample. For Net Equity Issues the increase is $1.6 \%$ in the more dependent sample versus $1.2 \%$ in the less dependent sample for the weak euro firms.

The results in Table 5 show that the introduction of the euro has improved access to financing, since more external finance dependent firms have experienced consistently larger increases. This is especially true for weak euro firms and their debt financing. To further examine the role of access to financing and financial integration, we analyze financing activities conditional on firm size. As shown by Gozzi, Levine, and Schmukler (2010) very few firms account for a large portion of international capital raisings. Based on the evidence provided by Gozzi et al. we would expect the effect of the euro to be greater for larger firms.

In Table 6, we split the sample between large and small firms and estimate our baseline regressions for each subsample. We first rank firms based on average yearly sales in real USD over the 1991-1997 time period. Next we designate firms as large if they have higher average sales than the sample median, otherwise they are classified as small. Panel A of Table 6 displays the results for large firms and Panel B does the same for small firms. Consistent with our conjecture, we see that large euro firms have experienced a comparatively greater increase in external financing following the introduction of the euro. Moreover, the difference relative to smaller euro firms is largely due to greater debt financing. 


\section{Financial integration and financing activities}

Although the euro was adopted as the common currency in 1999, it might have taken much longer for the effects of the common currency to filter through to deepening financial integration. In Table 7 we further examine this by splitting the post-euro time period into one earlier period 1999-2002and one later period (2003-2006). If euro firms only increase external financing as a response to lower cost of capital and increased investment opportunities we would expect a relatively immediate increase in external financing because such positive demand shocks have been immediately recognized by financial markets and incorporated in company valuations when the euro was introduced (see Bris, Koskinen, and Nilsson, 2009). On the other hand, it could be that it takes a longer time for the institutions of financial markets to change and thus also longer time for deepening financial integration to have an impact on corporate decisions. Table 7 shows that the increase in external financing is concentrated for the years 2003-2006, supporting the hypothesis that changing financial institutions and resulting improved access to financing are the main drivers for our results. During the latter period both debt and equity financing increased for all euro firms. During the earlier period only the weak euro countries experienced increases in external financing. In addition, the effects for weak euro firms are significantly stronger for the latter period; the overall magnitude is about three times larger.

By splitting the post-euro time to two periods and showing that the effects on financing are much larger in the latter period provides indirect evidence on the mechanisms of financial integration. We can also provide some direct evidence on the mechanisms of integration, since the introduction of the euro has also been followed by legal-regulatory harmonization across all of the European Union (EU). Following Kalemli-Ozcan, Papaioannou, and Peydró (2010), we consider the impact of the Financial Services Action Plan (FSAP) on corporate financing choices. FSAP was an initiative launched by the EU Commission and the EU Council in the late 1990s with the goal of harmonizing the financial intermediary market within the EU. The FSAP included various directives for new legislation to be adopted by the member countries. The directives introduce new EU-wide legislation regarding securities settlements, 
rules for bank reorganizations, money laundering, consumer protection in financial services, crosscountry mergers, insider dealing and market manipulation and transparency in securities markets. By establishing common rules these directives made financial integration more feasible.

Empirical identification of the effect of FSAP implementation on corporate financing activities is facilitated by the fact that we have both cross-sectional and intertemporal heterogeneity in our sample with respect to FSAP implementation. In the cross-section, our sample contains two non-EU member countries (Norway and Switzerland) that are not part of FSAP, and firms from these two countries are thus our outright control sample. Intertemporally, we have variation across the EU-member states as to the implementation dates of different FSAP Directives. During our sample period 27 different directives had been initiated. However, the EU countries have discretion as to when the implementation of the directives into nation laws takes place. Delays of implementation by any member country are due to various technical and political reasons, with the end result that the date of implementation for any given directive can differ greatly across the EU-countries. Given our particular sample period, we will not consider implementation of directives that took place after 2005. This means that five out of the 27 issued directives are immediately excluded from the analysis. The remaining 22 Directives relate to three main financial intermediary markets: (i) banking (five directives), (ii) securities (ten directives), and (iii) insurance (seven directives). We gather the data on the directives and their implementation dates from Kalemli-Ozcan, Papaioannou, and Peydro (2010). ${ }^{8}$

The variable we use in our regression analysis to capture the effect of an individual countries' legal implementation of the directives is FSAP index, defined as $\log (1+$ cumulative directive transpositions at year $t$ for country $i$ ). This variable will always have a value of zero for firms from the two non-EU countries. This variable is lagged one year relative to the dependent variables. We construct the index using only the directives within the banking and securities areas, since those are the two most directly relevant intermediary markets for corporations. A full list of the fifteen specific directives we thus

\footnotetext{
${ }^{8}$ See Kalemli-Ozcan, Papaioannou, and Peydró (2010) for a more detailed discussion on the FSAP directives and their transposition dates by member countries.
} 
consider is listed in Appendix D. The number of these directives cumulatively adopted any given year by an EU member state range from zero to twelve during our sample period.

Table 8 presents the results of our analysis. Columns (1) and (2) show that adding the FSAP index by itself does not alter our previous results regarding the impact of the euro on Net External Finance. However, when we also include an interaction of FSAP index with the euro firm indicator in Columns (3) and (4), we find that there is a significantly positive marginal effect of the FSAP directives on Net External Finance when the firm is a euro firm. The coefficient of FSAP index itself remains insignificant. At the same time, the magnitude of the basic effect of being a euro firm is reduced. This pattern of results is repeated also for Net Debt Issues and Net Equity Issues. It thus seems that there are complementarities between adopting the euro, and adopting a common legal framework for financial intermediation.

\section{The effect of the euro on asset growth and corporate payout}

So far we have documented a significant increase in external financing among euro firms following the introduction of the euro, in particular among firms from countries that suffered devaluations during the ERM crisis (i.e. the weak euro countries). In this section we analyze what these new funds have been used for. In principal, new external funds would have to be used for asset growth or to increase the payout to shareholders. Given the magnitude of the increase in financing, it is reasonable to expect that most of the funds have been used for asset growth. However, the type of asset growth should be able to tell us more about why the euro has facilitated an increase in external financing. If the euro has permanently improved the access to capital and lowered the cost of capital we would expect firms to mainly use any new funds raised to invest in productive assets. However, to the extent that firms believe the euro effect is temporary, we would expect firms to take the opportunity to increase their cash holdings to save for the future when financing conditions are expected to return to normal.

In Table 9 we analyze to what extent the documented increase in external financing due to the euro is connected to asset growth versus an increase in dividends and total payouts, and also whether we 
see a growth in non-cash assets versus cash holdings. To capture asset growth we use the variable Change in Assets, defined as the change in the total book value of assets during the year divided by the beginningof-year book value of assets. This variable is thus the growth rate in total assets. Growth in non-cash assets is captured by the variable Change in Non-Cash Assets, defined as the change in non-cash assets (=total assets minus cash and short-term investments) over the year divided by the beginning-of-year book value of assets. The growth rate in non-cash assets is thus expressed as a fraction of all assets. Similarly the growth in cash holdings is measured by Change in Cash Holdings, defined as the change in cash and short-term investments over the year divided by the beginning-of-year book value of assets. We then measure Dividends as yearly dividends divided by the beginning-of-year book value of assets. Firms could have also initiated stock repurchase programs. To capture this possibility we measure Total Payouts as yearly dividends plus stock repurchases divided by the beginning-of-year book value of assets. All five of these dependent variables are winsorized at their $1^{\text {st }}$ and $99^{\text {th }}$ percentile values. In each regression of Table 9 we included the same set of independent variables used in the external financing regressions (see Table 2).

Panel A of Table 9 presents the regression results for the full sample of firms. Euro firms have increased their total assets by $3.7 \%$ annually (significant at the $10 \%$-level). The effect is concentrated on weak euro firms: an increase of $7.1 \%$ (significant at the $1 \%$-level). The euro has no effect on dividends nor on total payouts. Moreover, we see that the whole increase in total assets is due to a significant increase in non-cash assets; there is no significant effect on cash holdings. This result suggests that firms expect the positive effects of the euro to be permanent. The results in Panel A are consistent with an increase in the supply of capital, but also with firms reacting to an increase in investment opportunities (demand effect).

We know from Table 5 that euro firms in more external finance dependent industries increased their external financing comparatively more, which support that an increase if the supply of capital is an important driver of the overall results. In Panels B and C of Table 9 we similarly split the firms depending on external finance dependence to check that the external financing results also carry over to asset 
growth. Panel B presents the results for more external finance dependent industries, and Panel C presents results for less external finance dependent industries. Results are very strong for firms in more finance dependent industries. The increase in total assets for weak euro firms is $9.9 \%$, solely attributable to noncash assets. Even strong euro firms increase their non-cash assets (an increase of 3.5\%). In less finance dependent industries results are weaker and significant only for weak euro firms.

In Panel D we split the post-euro time to early (1999-2002) and late (2003-2006) time periods. Consistent with the financing results, firms have increased their non-cash assets more during the latter period: for the early period, weak euro firms increase their non-cash assets by $4.3 \%$, in the late period by 10.8\%. The strong euro firms only exhibit an increase in the late period, when non-cash assets grow by $6.5 \%$.

\section{Conclusions}

We provide evidence that the firms in the euro area increased external financing before the crisis, compared to the firms from countries that didn't adopt the euro. This is especially true for debt financing. Our firm-level evidence is consistent with the aggregate-level results of Lane (2013), who shows that capital flows in the euro area were dominated by debt investments prior to the global financial crisis. Our results are stronger for firms from countries that previously had weak currencies and for firms that have the lowest foreign sales. These results are consistent with the view that firms have increased financing because cost of financing decreased. We also find evidence that increased access to financing has been a major contributing factor in explaining increased use of external financing. Firms that were likely to be financially constrained prior to the introduction of the euro should experience the largest increases in external financing. Supporting this hypothesis, we find that firms in industries that are more dependent on external financing have increased their debt financing more. Interestingly, we also find that large firms have increased their debt financing more. At first sight this result is counter-intuitive, since arguably small firms are more financially constrained than large firms. However, financial integration is more 
likely to improve access to financing for larger firms, since typically only a few large firms account for a significant proportion of international debt financing (Gozzi, Levine, and Schmukler, 2010).

Improved access to financing, however, could be a double-edged sword. As shown by Maddaloni and Peydro (2011), softer lending standards fostered by low short-term interest rates before the crisis have led to worse economic performance during the crisis. Our evidence suggests that firms believed that the euro had positively altered the economic environment for the euro area and that the euro crisis was completely unexpected. This is manifested in firms' investment behavior: increased financing led to increased investments. If firms had thought that rougher times lay ahead, a prudent action would have been to increase their cash holdings. Given the beliefs and resulting stock valuations that prevailed prior to the crisis, it is difficult to claim firms financial behavior was reckless ex-ante. Consistent with this view, we can show that market leverage didn't increase for the euro area firms prior to the crisis, despite the significant increases in debt financing. ${ }^{9}$ Stock valuations have turned out to be optimistic ex-post, but ex-ante the increase in debt financing seems to have been a rational response to a decrease in cost of financing and improved access to capital.

\footnotetext{
${ }^{9}$ These leverage results can be obtained from the authors upon request.
} 


\section{Appendix A. Variable definitions}

\begin{tabular}{|c|c|}
\hline Variable & Definition (item \# refers to Worldscope field) \\
\hline Net Debt Issues & 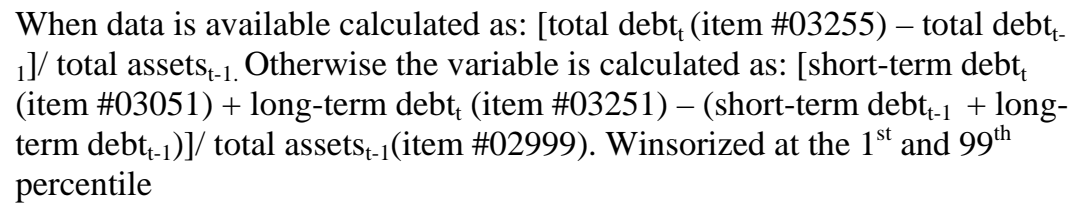 \\
\hline Net Equity Issues & 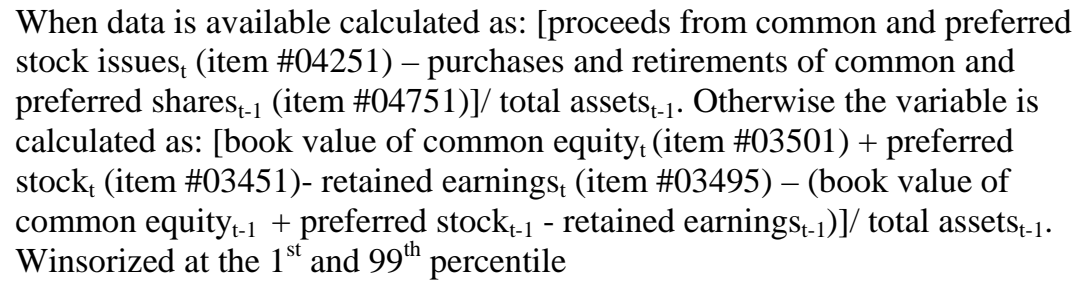 \\
\hline Net External Finance & $\begin{array}{l}\text { The sum of net debt and equity issues as defined above. Winsorized at the } \\
1^{\text {st }} \text { and } 99^{\text {th }} \text { percentile }\end{array}$ \\
\hline
\end{tabular}

Change in USD Exchange Rate

Change in Total Assets

Change in Cash Holdings

Change in Non-Cash Assets

Dividends

Total Payouts

I(Euro Country)

I(Strong Euro Country)

I(Weak Euro Country)

I(Post Euro)

US industry Q

Log (Sales)

EBITDA/assets
[Domestic currency/USD end-of-year exchange rate in year $t$-domestic currency/USD end-of-year exchange rate in year $t$-1]/domestic currency/USD end-of-year exchange rate in year $t-1$.

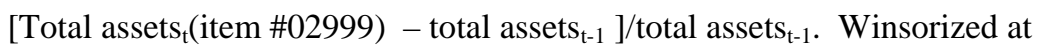
the $1^{\text {st }}$ and $99^{\text {th }}$ percentile

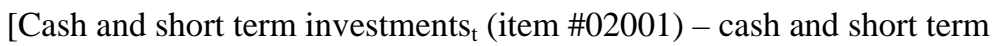

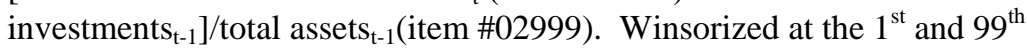
percentile

Change in Total Assets - Change in Cash Holdings. Winsorized at the $1^{\text {st }}$ and $99^{\text {th }}$ percentile

Dividends paid $_{\mathrm{t}}$ (item \#04551)/total assets $_{\mathrm{t}-1}$ (item \#02999). Winsorized at the $1^{\text {st }}$ and $99^{\text {th }}$ percentile

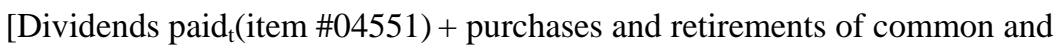

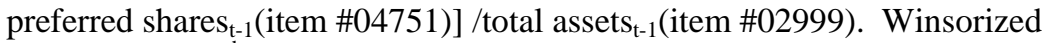
at the $1^{\text {st }}$ and $99^{\text {th }}$ percentile

Indicator variable $=1$ if the firm comes from Austria, Belgium, Finland, France, Germany, Ireland, Italy, Luxembourg, the Netherlands, Portugal, or Spain; zero otherwise

Indicator variable $=1$ if the firm comes from Austria, Belgium, France, Germany, Luxembourg, or the Netherlands, Portugal; zero otherwise Indicator variable $=1$ if the firm comes from Finland, Ireland, Italy, , Portugal, or Spain; zero otherwise

Indicator variable $=1$ if the time period is 1999-2006; zero otherwise

The median US firm Q in each two-digit SIC code industry, calculated using all US firms with available data on Tobin's Q in Compustat. Tobin's Q is calculated as [the book value of assets - the book value of equity + market value of equity/ book value of total assets. This variable is lagged one year.

The natural logarithm of net sales (item \# 01001) expressed in real USD (baseline year $=2000$ ). This variable is lagged one year and Winsorized at the $1^{\text {st }}$ and $99^{\text {th }}$ percentile.

Earnings before interest, taxes, and depreciation and amortization (item \#18198 or, alternatively, item \#18191 + item \#01151)/total assets (item $\# 02999)$. This variable is lagged one year and Winsorized at the $1^{\text {st }}$ and $99^{\text {th }}$ percentile. 
Appendix A (continued)

\begin{tabular}{ll}
\hline Variable & Definition (item \# refers to Worldscope field) \\
\hline Collateral/assets & [Net property, plant, and equipment (item \#02501) + inventories (item \\
& $\begin{array}{l}\# 02101)] / \text { total assets(item \#02999) . This variable is lagged one year and } \\
\text { Winsorized at the } 1^{\text {st }} \text { and } 99^{\text {th }} \text { percentile. }\end{array}$ \\
$I($ Leverage $>90 \%)$ & $\begin{array}{l}\text { Indicator variable }=1 \text { if Total liabilities/BV of assets }>90 \% \text {; zero otherwise. } \\
\text { This variable is lagged one year. }\end{array}$ \\
GDP Growth & $\begin{array}{l}\text { Individual country real GDP growth (in USD terms). This variable is lagged } \\
\text { one year. } \\
\text { Term spread }\end{array}$ \\
& $\begin{array}{l}\text { Difference in yields between } 10 \text { year government bond and } 6 \text { month treasury } \\
\text { bill for each individual sample country. This variable is lagged one year. }\end{array}$ \\
\hline
\end{tabular}




\section{Appendix B}

Summary statistics

This table presents average values for firm and country characteristics by country and EMU membership status (euro vs. non-euro countries). The sample is an unbalanced panel of 2,486 firms (29,932 firm-years) from eleven euro countries and five non-euro countries with data available in Worldscope over the time period 1991-2006. See Appendix A for variable definitions.

\begin{tabular}{|c|c|c|c|c|c|c|c|c|c|c|c|c|c|}
\hline \multirow[b]{2}{*}{ Country } & \multicolumn{9}{|c|}{ Firm characteristics } & \multicolumn{4}{|c|}{ Country characteristics } \\
\hline & \#firms & $\begin{array}{c}\text { \# firm-year } \\
\text { obs }\end{array}$ & $\begin{array}{c}\text { Net External } \\
\text { Finance } \\
\end{array}$ & $\begin{array}{l}\text { Net Debt } \\
\text { Issues }\end{array}$ & $\begin{array}{c}\text { Net Equity } \\
\text { Issues }\end{array}$ & $\begin{array}{c}\text { U.S. } \\
\text { Industry } \\
\text { Q }\end{array}$ & Log(Sales) & $\begin{array}{l}\text { EBITDA/ } \\
\text { Assets }\end{array}$ & $\begin{array}{l}\text { Collateral/ } \\
\text { Assets }\end{array}$ & $\begin{array}{c}\text { \# Country- } \\
\text { year obs }\end{array}$ & $\begin{array}{c}\text { GDP } \\
\text { Growth }\end{array}$ & $\begin{array}{l}\text { Term } \\
\text { Spread }\end{array}$ & $\begin{array}{c}\text { Change in } \\
\text { USD FX } \\
\text { Rate }\end{array}$ \\
\hline Austria & 59 & 662 & 0.031 & 0.024 & 0.007 & 1.33 & 19.3 & 0.112 & 0.532 & 16 & 0.023 & 1.21 & 0.007 \\
\hline Belgium & 37 & 418 & 0.036 & 0.024 & 0.010 & 1.45 & 20.3 & 0.132 & 0.494 & 16 & 0.020 & 1.31 & 0.007 \\
\hline Finland & 76 & 975 & 0.020 & 0.007 & 0.011 & 1.45 & 19.4 & 0.138 & 0.510 & 16 & 0.021 & 1.38 & -0.004 \\
\hline France & 366 & 4,257 & 0.033 & 0.019 & 0.013 & 1.51 & 19.7 & 0.124 & 0.390 & 16 & 0.019 & 0.83 & 0.008 \\
\hline Germany & 376 & 4,496 & 0.028 & 0.018 & 0.010 & 1.46 & 19.8 & 0.134 & 0.524 & 16 & 0.018 & 1.05 & 0.007 \\
\hline Ireland & 37 & 471 & 0.081 & 0.043 & 0.034 & 1.43 & 19.3 & 0.102 & 0.545 & 16 & 0.067 & 0.52 & 0.003 \\
\hline Italy & 114 & 1,438 & 0.038 & 0.026 & 0.010 & 1.42 & 20.0 & 0.112 & 0.435 & 16 & 0.014 & 1.15 & -0.008 \\
\hline Luxemburg & 6 & 74 & 0.040 & 0.018 & 0.026 & 1.41 & 20.4 & 0.148 & 0.524 & 16 & 0.047 & 0.60 & 0.007 \\
\hline Netherlands & 123 & 1,527 & 0.049 & 0.029 & 0.019 & 1.49 & 20.1 & 0.150 & 0.510 & 16 & 0.026 & 1.17 & 0.007 \\
\hline Portugal & 55 & 575 & 0.057 & 0.038 & 0.019 & 1.47 & 18.8 & 0.115 & 0.527 & 16 & 0.023 & 0.32 & -0.001 \\
\hline Spain & 99 & 1,205 & 0.054 & 0.032 & 0.019 & 1.43 & 19.8 & 0.117 & 0.527 & 16 & 0.030 & 0.79 & -0.009 \\
\hline All euro countries & 1,348 & 16,098 & 0.037 & 0.022 & 0.013 & 1.46 & 19.7 & 0.127 & 0.479 & 176 & 0.028 & 0.94 & 0.002 \\
\hline Denmark & 120 & 1,454 & 0.036 & 0.026 & 0.009 & 1.52 & 18.9 & 0.124 & 0.536 & 16 & 0.021 & 0.73 & 0.007 \\
\hline Norway & 76 & 830 & 0.064 & 0.032 & 0.027 & 1.47 & 19.0 & 0.116 & 0.501 & 16 & 0.031 & 0.31 & 0.002 \\
\hline Sweden & 116 & 1,360 & 0.040 & 0.018 & 0.019 & 1.53 & 19.7 & 0.119 & 0.485 & 16 & 0.021 & 0.81 & -0.003 \\
\hline Switzerland & 128 & 1,667 & 0.017 & 0.009 & 0.008 & 1.53 & 19.9 & 0.114 & 0.522 & 16 & 0.013 & 0.76 & 0.008 \\
\hline United Kingdom & 696 & 8,523 & 0.058 & 0.024 & 0.029 & 1.50 & 19.1 & 0.122 & 0.527 & 16 & 0.023 & 0.07 & 0.005 \\
\hline All non-euro countries & 1,138 & 13,834 & 0.049 & 0.022 & 0.023 & 1.51 & 19.2 & 0.121 & 0.522 & 80 & 0.022 & 0.53 & 0.004 \\
\hline All countries & 2,486 & 29,932 & 0.042 & 0.022 & 0.018 & 1.48 & 19.5 & 0.124 & 0.499 & 256 & 0.026 & 0.81 & 0.003 \\
\hline
\end{tabular}




\section{Appendix C}

The effect of the late convergence period on financing activities

The table presents panel data OLS regressions estimating the effect of the introduction of the euro on corporate financing activity split by different industry groups. The sample is an unbalanced panel of firms from eleven euro countries (Austria, Belgium, Finland, France, Germany, Ireland, Italy, Luxembourg, the Netherlands, Portugal, and Spain) and five non-euro countries (Denmark, Norway, Sweden, Switzerland, and U.K.) over the time period 1991-1998. I(Euro Country) is an indicator variable equal to one if the firm belongs to a euro country, and is zero otherwise. Strong euro countries are the countries that are classified as having strong currencies prior to adopting the euro (i.e., Austria, Belgium, France, Germany, Luxembourg, and the Netherlands). Weak euro countries are the countries that are classified as having weak currencies prior to adopting the euro (i.e., Finland, Ireland, Italy, Portugal, and Spain).The late convergence period is defined as the years 1997 and 1998, i.e., the time period when the EMU candidate countries made final preparations to qualify for actually adopting the euro on January $1^{\text {st }}$, 1999. See Appendix A for other variable definitions. Standard errors clustered at the country level are reported within brackets. * and **, indicates significance at the 5\%-, and 1\%-levels, respectively.

\begin{tabular}{|c|c|c|c|c|c|c|}
\hline \multirow[b]{3}{*}{ Explanatory variable: } & \multicolumn{6}{|c|}{ Dependent variable: } \\
\hline & \multicolumn{2}{|c|}{ Net External Finance } & \multicolumn{2}{|c|}{ Net Debt Issues } & \multicolumn{2}{|c|}{ Net Equity Issues } \\
\hline & $(1)$ & $(2)$ & $(3)$ & $(4)$ & $(5)$ & (6) \\
\hline$I($ Euro Country) x I(Late Convergence Period) & $\begin{array}{c}-0.019 \\
(0.014)\end{array}$ & & $\begin{array}{c}-0.016 \\
(0.012)\end{array}$ & & $\begin{array}{c}-0.004 \\
(0.004)\end{array}$ & \\
\hline$I$ (Strong Euro Country) x I(Late Convergence Period) & & $\begin{array}{c}-0.028 \\
(0.016)\end{array}$ & & $\begin{array}{c}-0.023 \\
(0.014)\end{array}$ & & $\begin{array}{c}-0.006 \\
(0.005)\end{array}$ \\
\hline I(Weak Euro Country) x I(Late Convergence Period) & & $\begin{array}{c}-0.002 \\
(0.013)\end{array}$ & & $\begin{array}{c}-0.003 \\
(0.013)\end{array}$ & & $\begin{array}{c}-0.001 \\
(0.004)\end{array}$ \\
\hline U.S. Industry Q & $\begin{array}{c}0.044^{* * *} \\
(0.012)\end{array}$ & $\begin{array}{c}0.044^{* * *} \\
(0.012)\end{array}$ & $\begin{array}{c}0.026 * * * \\
(0.006)\end{array}$ & $\begin{array}{c}0.026 * * * \\
(0.006)\end{array}$ & $\begin{array}{c}0.013^{* *} \\
(0.006)\end{array}$ & $\begin{array}{c}0.013^{* *} \\
(0.006)\end{array}$ \\
\hline Log(Sales) & $\begin{array}{c}-0.083 * * * \\
(0.012)\end{array}$ & $\begin{array}{c}-0.083^{* * *} \\
(0.012)\end{array}$ & $\begin{array}{c}-0.042^{* * *} \\
(0.004)\end{array}$ & $\begin{array}{c}-0.042 * * * \\
(0.004)\end{array}$ & $\begin{array}{c}-0.033 * * \\
(0.011)\end{array}$ & $\begin{array}{c}-0.033^{* *} \\
(0.011)\end{array}$ \\
\hline EBITDA/Assets & $\begin{array}{c}0.296^{* * *} \\
(0.051)\end{array}$ & $\begin{array}{c}0.294^{* * *} \\
(0.050)\end{array}$ & $\begin{array}{c}0.236^{* * *} \\
(0.026)\end{array}$ & $\begin{array}{c}0.233^{* * *} \\
(0.026)\end{array}$ & $\begin{array}{c}0.051 \\
(0.029)\end{array}$ & $\begin{array}{c}0.050 \\
(0.029)\end{array}$ \\
\hline Collateral/Assets & $\begin{array}{c}-0.005 \\
(0.045)\end{array}$ & $\begin{array}{c}-0.007 \\
(0.045)\end{array}$ & $\begin{array}{c}-0.043 \\
(0.024)\end{array}$ & $\begin{array}{c}-0.044 * \\
(0.025)\end{array}$ & $\begin{array}{c}0.028 \\
(0.026)\end{array}$ & $\begin{array}{c}0.027 \\
(0.026)\end{array}$ \\
\hline$I($ Leverage $>90 \%)$ & $\begin{array}{c}-0.050 * * * \\
(0.017)\end{array}$ & $\begin{array}{c}-0.050 * * * \\
(0.017)\end{array}$ & $\begin{array}{c}-0.065^{* * *} \\
(0.018)\end{array}$ & $\begin{array}{c}-0.065^{* * *} \\
(0.018)\end{array}$ & $\begin{array}{c}0.018^{* *} \\
(0.007)\end{array}$ & $\begin{array}{c}0.018 * * \\
(0.007)\end{array}$ \\
\hline GDP Growth & $\begin{array}{c}0.458^{* *} \\
(0.160)\end{array}$ & $\begin{array}{l}0.346^{*} \\
(0.197)\end{array}$ & $\begin{array}{c}0.498 * * * \\
(0.140)\end{array}$ & $\begin{array}{c}0.411^{* *} \\
(0.167)\end{array}$ & $\begin{array}{c}-0.007 \\
(0.074)\end{array}$ & $\begin{array}{c}-0.029 \\
(0.085)\end{array}$ \\
\hline Term Spread & $\begin{array}{c}-0.263 \\
(0.201)\end{array}$ & $\begin{array}{l}-0.086 \\
(0.232)\end{array}$ & $\begin{array}{c}-0.300^{*} \\
(0.170)\end{array}$ & $\begin{array}{c}-0.163 \\
(0.191)\end{array}$ & $\begin{array}{c}0.026 \\
(0.087)\end{array}$ & $\begin{array}{c}0.061 \\
(0.104)\end{array}$ \\
\hline Change in USD Exchange Rate & $\begin{array}{c}-0.076^{*} \\
(0.039)\end{array}$ & $\begin{array}{l}-0.074 * \\
(0.037)\end{array}$ & $\begin{array}{c}-0.088^{* *} \\
(0.033)\end{array}$ & $\begin{array}{c}-0.087 * * \\
(0.032)\end{array}$ & $\begin{array}{c}0.001 \\
(0.007)\end{array}$ & $\begin{array}{c}0.001 \\
(0.007)\end{array}$ \\
\hline Year Dummies and Fixed Firm Effects & YES & YES & YES & YES & YES & YES \\
\hline $\mathrm{R}^{2}$ & 0.34 & 0.34 & 0.26 & 0.26 & 0.34 & 0.34 \\
\hline Number of Firm-Year Observations & 15,568 & 15,568 & 15,568 & 15,568 & 15,568 & 15,568 \\
\hline Number of Firms & 2,486 & 2,486 & 2,486 & 2,486 & 2,486 & 2,486 \\
\hline
\end{tabular}




\section{Appendix D. List of Financial Services Action Plan (FSAP) directives included in FSAP index}

\begin{tabular}{|c|c|c|}
\hline Directive No & Directive Name & Category \\
\hline 1998/26/EC & Implementation of the Settlement Finality Directive & Securities \\
\hline 2000/46/EC & $\begin{array}{l}\text { Directive on the taking up, pursuit and prudential supervision of the businesses } \\
\text { of electronic money institutions }\end{array}$ & Banking \\
\hline 2001/24/EC & Directive on the reorganization and winding up of banks & Banking \\
\hline 2001/65/EC & $\begin{array}{l}\text { Directive amending the 4th and 7th Company Law Directives to allow fair } \\
\text { value accounting }\end{array}$ & Securities \\
\hline 2001/86/EC & $\begin{array}{l}\text { Directive supplementing the Statute for a European Company with regard to } \\
\text { the involvement of employees }\end{array}$ & Securities \\
\hline 2001/97/EC & Directive amending the money laundering directive & Banking \\
\hline 2001/107/EC & $\begin{array}{l}\text { 1st Directive on UCITS (Undertakings for Collective Investments in } \\
\text { Transferable Securities) }\end{array}$ & Securities \\
\hline 2001/108/EC & $\begin{array}{l}\text { 2nd Directive on UCITS (Undertakings for Collective Investments in } \\
\text { Transferable Securities) }\end{array}$ & Securities \\
\hline 2002/47/EC & Directive on financial collateral arrangements & Securities \\
\hline 2002/87/EC & $\begin{array}{l}\text { Directive on the supervision of credit institutions, insurance undertakings and } \\
\text { investment firms in a financial conglomerate }\end{array}$ & Banking \\
\hline 2003/6/EC & Directive on insider dealing and market manipulation & Securities \\
\hline 2003/48/EC & Directive on the taxation of savings income in the form of interest payments & Banking \\
\hline 2003/51/EC & $\begin{array}{l}\text { Directive modernizing the accounting provisions of the 4th and 7th Company } \\
\text { Law Directive }\end{array}$ & Securities \\
\hline 2003/71/EC & Directive on prospectuses & Securities \\
\hline 2004/25/EC & Directive on Take Over Bids & Securities \\
\hline
\end{tabular}




\section{References}

Baele, L., Ferrando, A., Hördahl, P., Krylova, E., Monnet, C., 2004. Measuring European financial integration. Oxford Review of Economic Policy 20, 509-530.

Beetsma, R., Giuliodori, M., 2010. The macroeconomic costs and benefits of the EMU and other monetary unions: An overview of recent research. Journal of Economic Literature 48, 603-641.

Bekaert, G., Harvey, C. R., Lundblad, C. T., Siegel, S., 2013, The European Union, the euro, and equity market integration. Journal of Financial Economics 109, 583-603.

Bris, A., Koskinen, Y., Nilsson, M., 2006. The real effects of the euro: Evidence from corporate investments. Review of Finance 10, 1-37.

Bris, A., Koskinen, Y., Nilsson, M., 2009. The euro and corporate valuations. Review of Financial Studies 22, 3171-3209.

Caballero, R. J., Krishnamurthy, A., 2001. International and Domestic Collateral Constraints in a Model of Emerging Market Crisis, Journal of Monetary Economics 48, 513-548.

Cappiello, L., Kadareja, A., Manganelli, S., 2010. The impact of the euro on equity markets. Journal of Financial and Quantitative Analysis 45, 473-502.

Coeurdacier, N., Martin, P., 2009. The geography of asset trade and the euro: Insiders and outsiders. Journal of the Japanese and International Economies, 23, 90-113.

De Santis, R. A., Gerard, B., 2006. Financial integration, international portfolio choice and the European Monetary Union. European Central Bank Working Paper No. 626.

European Commission, 2008. EMU@10: Successes and challenges after ten years of Economic and Monetary Union. European Economy 2.

Faulkender, M., Petersen, M., 2006. Does the source of capital affect capital structure?. Review of Financial Studies 19, 45-79.

Gozzi, J. C., Levine R., Schmukler, S. L., 2010. Patterns of international capital raisings. Journal of International Economics 80, 45-57.

Hardouvelis, G. A., Malliaropulos, D., Priestley, R., 2006. EMU and European stock market integration, Journal of Business 79, 365-392.

Hardouvelis, G. A., Malliaropulos, D., Priestley, R., 2007. The Impact of EMU on the equity cost of capital. Journal of International Money and Finance 26, 305-327.

Hassan, T. A., 2013. Country size, currency unions, and international asset returns. Journal of Finance 68, 2269-2308.

Kalemli-Ozcan, S., Papaioannou, E., Peydro, J.-L., 2010. What lies beneath the euro’s effect on financial integration? Currency risk, legal harmonization, or trade? Journal of International Economics 81, 7588. 
Lane, P. R., 2006. Global bond portfolios and EMU. International Journal of Central Banking 2, 1-23.

Lane, P. R., 2012. The European sovereign debt crisis. Journal of Economic Perspectives 26, 49-68.

Lane, P. R., 2013. Capital flows in the euro area. CEPR Discussion Paper No. 9493.

Lane, P. R., Milesi-Ferretti, G. M., 2007. The international equity holdings of euro area investors. In Anderton, R., Di Mauro, F. (Eds.), The External Dimension for the Euro Area: Assessing the Linkages. Cambridge University Press.

Leary, M. T., 2009. Bank loan supply, lender choice, and corporate capital structure. Journal of Finance 64, 1143-1185.

Lemmon, M., Roberts, M. R., 2010. The response of corporate financing and investment to changes in the supply of credit. Journal of Financial and Quantitative Analysis, 45, 555-587.

Maddaloni, A., Peydro, J.-L., 2011. Bank risk-taking, securitization, supervision, and low interest rates: Evidence from the euro-area and the U.S. lending standards. Review of Financial Studies, 24, 21212165.

Rajan, R. G., Zingales, L., 1998. Financial dependence and growth. American Economic Review 88, 55958.

Roberts, M. R., Whited, T. M., 2013. Endogeneity in empirical corporate finance. In Constantinides, G., Harris, M., Stulz, R. (Eds.), Handbook of the Economics of Finance, Volume 2, Part A. Elsevier, Amsterdam, pp. 493-572.

Sufi, A., 2009. The real effects of debt certification: evidence from the introduction of bank loan ratings. Review of Financial Studies 22, 1659-1691. 
Table 1

Financing activity before and after the introduction of the euro

The sample is an unbalanced panel of firms from eleven Euro countries (Austria, Belgium, Finland, France, Germany, Ireland, Italy, Luxembourg, the Netherlands, Portugal, and Spain) and five Non-euro countries (Denmark, Norway, Sweden, Switzerland, and U.K.) over the time period 1991-2006. The post-euro time period is defined as the years 1999-2006. See Appendix A for variable definitions.

\begin{tabular}{|c|c|c|c|c|c|}
\hline \multicolumn{6}{|l|}{ Panel A: Average Net External Finance } \\
\hline & \# of firms & $\begin{array}{l}\text { Pre-euro time } \\
\text { period }\end{array}$ & $\begin{array}{l}\text { Post-euro time } \\
\text { period }\end{array}$ & $\begin{array}{l}\text { Difference } \\
\text { (Post - Pre) }\end{array}$ & $\begin{array}{r}T \text {-test of } \\
\text { difference }\end{array}$ \\
\hline Euro countries & 1,348 & 0.040 & 0.038 & -0.002 & 0.72 \\
\hline Strong euro countries & 967 & 0.041 & 0.031 & -0.010 & $2.80^{* * *}$ \\
\hline Weak euro countries & 381 & 0.037 & 0.055 & 0.018 & $2.43^{* * *}$ \\
\hline Non-euro countries & 1,138 & 0.074 & 0.044 & -0.030 & $6.79 * *$ \\
\hline \multicolumn{6}{|l|}{$T$-test: } \\
\hline Euro vs. non-euro countries & & $7.00 * * *$ & 1.57 & $4.91^{* * *}$ & \\
\hline Strong-euro vs. non-euro countries & & $6.47 * * *$ & $3.04 * * *$ & $3.34 * * *$ & \\
\hline Weak euro vs. non-euro countries & & $5.47 * * *$ & $1.72 *$ & $5.56 * * *$ & \\
\hline Strong- vs. weak-euro countries & & 0.73 & $4.20 * * *$ & $3.43^{* * *}$ & \\
\hline \multicolumn{6}{|l|}{ Panel B: Average Net Debt Issues } \\
\hline & \# of firms & $\begin{array}{l}\text { Pre-euro time } \\
\text { period }\end{array}$ & $\begin{array}{l}\text { Post-euro time } \\
\text { period }\end{array}$ & $\begin{array}{l}\text { Difference } \\
\text { (Post - Pre) }\end{array}$ & $\begin{array}{r}T \text {-test of } \\
\text { difference }\end{array}$ \\
\hline Euro countries & 1,348 & 0.022 & 0.025 & 0.003 & 1.12 \\
\hline Strong euro countries & 967 & 0.024 & 0.020 & -0.004 & 1.45 \\
\hline Weak euro countries & 381 & 0.007 & 0.037 & 0.030 & $4.15^{* * *}$ \\
\hline Non-euro countries & 1,138 & 0.030 & 0.023 & -0.006 & $2.32 * * *$ \\
\hline \multicolumn{6}{|l|}{$T$-test: } \\
\hline Euro vs. non-euro countries & & $2.79 * * *$ & 0.61 & $2.49 * *$ & \\
\hline Strong-euro vs. non-euro countries & & $1.90 *$ & 1.02 & 0.62 & \\
\hline Weak euro vs. non-euro countries & & $3.28 * * *$ & $3.34^{* * *}$ & $4.76^{* * *}$ & \\
\hline Strong- vs. weak-euro countries & & $1.89 *$ & $4.08^{* * *}$ & $4.32 * * *$ & \\
\hline \multicolumn{6}{|l|}{ Panel C: Average Net Equity Issues } \\
\hline & \# of firms & $\begin{array}{c}\text { Pre-euro time } \\
\text { period }\end{array}$ & $\begin{array}{c}\text { Post-euro time } \\
\text { period }\end{array}$ & $\begin{array}{l}\text { Difference } \\
\text { (Post - Pre-) }\end{array}$ & $\begin{array}{r}T \text {-test of } \\
\text { difference }\end{array}$ \\
\hline Euro countries & 1,348 & 0.016 & 0.012 & -0.004 & $2.55^{* *}$ \\
\hline Strong euro countries & 967 & 0.015 & 0.010 & -0.005 & $2.95^{* * *}$ \\
\hline Weak euro countries & 381 & 0.018 & 0.016 & -0.002 & 0.48 \\
\hline Non-euro countries & 1,138 & 0.038 & 0.018 & -0.021 & $8.93^{* * *}$ \\
\hline \multicolumn{6}{|l|}{$T$-test: } \\
\hline Euro vs. non-euro countries & & $8.32 * * *$ & $2.53^{* *}$ & $5.95 * * *$ & \\
\hline Strong-euro vs. non-euro countries & & $8.41 * * *$ & $3.19 * * *$ & $5.54 * * *$ & \\
\hline Weak euro vs. non-euro countries & & $5.59 * * *$ & 0.45 & $4.39 * * *$ & \\
\hline Strong- vs. weak-euro countries & & 0.82 & $1.98 * *$ & 0.79 & \\
\hline
\end{tabular}


Table 2

The effect of the euro on financing activities

The table presents panel data OLS regressions estimating the effect of the introduction of the euro on corporate financing activity as measured by three different dependent variables (Net External Finance, Net Debt Issues, and Net Equity Issues). The sample is an unbalanced panel of firms from eleven euro countries (Austria, Belgium, Finland, France, Germany, Ireland, Italy, Luxembourg, the Netherlands, Portugal, and Spain) and five non-euro countries (Denmark, Norway, Sweden, Switzerland, and U.K.) over the time period 1991-2006. I(Euro Country) is an indicator variable equal to one if the firm belongs to a euro country, and is zero otherwise. Strong euro countries are the countries that are classified as having strong currencies prior to adopting the euro (i.e., Austria, Belgium, France, Germany, Luxembourg, and the Netherlands). Weak euro countries are the countries that are classified as having weak currencies prior to adopting the euro (i.e., Finland, Ireland, Italy, Portugal, and Spain). I(Post-Euro) is an indicator variable equal to one if the observation is in the post-euro time period (i.e., 1999-2006), and is zero otherwise. The estimated coefficients on the interaction I(Euro Country) x I(Post-Euro) measures the average treatment effect from the introduction of the euro on the dependent variables. See Appendix A for other variable definitions. Standard errors clustered at the country level are reported within brackets. $*$ and $* *$, indicates significance at the 5\%-, and 1\%-levels, respectively.

\begin{tabular}{lcccccc}
\hline & \multicolumn{5}{c}{ Dependent variable: } \\
\cline { 2 - 7 } Explanatory variable: & \multicolumn{2}{c}{ Net External Finance } & Net Debt Issues & \multicolumn{2}{c}{ Net Equity Issues } \\
\cline { 2 - 7 } & $(1)$ & $(2)$ & $(3)$ & $(4)$ & $(5)$ & $(6)$ \\
\hline I(Euro Country) x I(Post-Euro) & $0.019^{*}$ & & 0.008 & & $0.010^{* * *}$ \\
& $(0.009)$ & & $(0.007)$ & & $(0.003)$ \\
I(Strong Euro Country) x I(Post-Euro) & & 0.009 & & 0.001 & & $0.008^{* *}$ \\
& & $(0.007)$ & & $(0.006)$ & & $(0.003)$ \\
$I$ (Weak Euro Country) x I(Post-Euro) & & $0.042^{* * *}$ & & $0.026^{* * *}$ & & $0.014^{* * *}$ \\
& & $(0.012)$ & & $(0.009)$ & & $(0.004)$ \\
U.S. Industry Q & $0.048^{* * *}$ & $0.048^{* * *}$ & $0.015^{* * *}$ & $0.015^{* * *}$ & $0.025^{* * *}$ & $0.025^{* * *}$ \\
& $(0.007)$ & $(0.006)$ & $(0.004)$ & $(0.004)$ & $(0.004)$ & $(0.004)$ \\
Log(Sales) & $-0.057^{* * *}$ & $-0.058^{* * *}$ & $-0.027^{* * *}$ & $-0.028^{* * *}$ & $-0.024^{* * *}$ & $-0.024^{* * *}$ \\
& $(0.007)$ & $(0.006)$ & $(0.002)$ & $(0.002)$ & $(0.005)$ & $(0.005)$ \\
EBITDA/Assets & $0.223^{* * *}$ & $0.222^{* * *}$ & $0.214^{* * *}$ & $0.213^{* * *}$ & 0.007 & 0.007 \\
& $(0.034)$ & $(0.034)$ & $(0.020)$ & $(0.019)$ & $(0.024)$ & $(0.024)$ \\
Collateral/Assets & 0.008 & 0.006 & -0.013 & -0.015 & 0.013 & 0.013 \\
& $(0.018)$ & $(0.019)$ & $(0.010)$ & $(0.010)$ & $(0.009)$ & $(0.009)$ \\
$I$ (Leverage>90\%) & $-0.034^{* *}$ & $-0.034^{* *}$ & $-0.049^{* * *}$ & $-0.049^{* * *}$ & $0.020^{* *}$ & $0.020^{* *}$ \\
& $(0.015)$ & $(0.015)$ & $(0.013)$ & $(0.013)$ & $(0.007)$ & $(0.007)$ \\
GDP Growth & $0.544^{* * *}$ & $0.496^{* * *}$ & $0.548^{* * *}$ & $0.512^{* * *}$ & 0.017 & 0.009 \\
& $(0.148)$ & $(0.132)$ & $(0.113)$ & $(0.112)$ & $(0.065)$ & $(0.061)$ \\
Term Spread & $-0.403^{*}$ & $-0.419^{*}$ & $-0.378^{*}$ & $-0.390^{*}$ & -0.031 & -0.034 \\
& $(0.195)$ & $(0.200)$ & $(0.188)$ & $(0.195)$ & $(0.064)$ & $(0.062)$ \\
Change in USD Exchange Rate & $-0.072^{*}$ & $-0.082^{*}$ & $-0.101^{* * *}$ & $-0.108^{* * *}$ & $0.018^{*}$ & 0.016 \\
& $(0.038)$ & $(0.040)$ & $(0.032)$ & $(0.034)$ & $(0.010)$ & $(0.010)$ \\
Year Dummies and Fixed Firm Effects & YES & YES & YES & YES & YES & YES \\
\hline R $^{2}$ & 0.22 & 0.22 & 0.16 & 0.16 & 0.24 & 0.24 \\
Number of Firm-Year Observations & 29,932 & 29,932 & 29,932 & 29,932 & 29,932 & 29,932 \\
Number of Firms & 2,486 & 2,486 & 2,486 & 2,486 & 2,486 & 2,486 \\
\hline
\end{tabular}


Table 3

The effect of the euro on financing activities: Individual country results

The table presents panel data OLS regressions estimating the effect of the introduction of the euro on corporate financing activity as measured by three different dependent variables (Net External Finance, Net Debt Issues, and Net Equity Issues). The sample is an unbalanced panel of firms from eleven euro countries (Austria, Belgium, Finland, France, Germany, Ireland, Italy, Luxembourg, the Netherlands, Portugal, and Spain) and five non-euro countries (Denmark, Norway, Sweden, Switzerland, and U.K.) over the time period 1991-2006. I(country name) is an indicator variable equal to one if the firm belongs to country in question, and is zero otherwise. I(Post-Euro) is an indicator variable equal to one if the observation is in the post-euro time period (i.e., 1999-2006), and is zero otherwise. Note that firms from United Kingdom constitute the benchmark sample in this table, and thus the estimated coefficients on I(country name) x I(Post-Euro) measures average treatment effects for firms in each respective country relative to firms in the United Kingdom. See Appendix A for other variable definitions. The same set of control variables as in Table 2 are included but not explicitly reported to conserve space. Full results are available from the authors upon request. Standard errors clustered at the country level are reported within brackets. * and ${ }^{* *}$, indicates significance at the 5\%-, and $1 \%$-levels, respectively.

\begin{tabular}{|c|c|c|c|}
\hline \multirow{2}{*}{ Explanatory variable: } & \multicolumn{3}{|c|}{ Dependent variable: } \\
\hline & $\begin{array}{l}\text { Net External } \\
\text { Finance }\end{array}$ & Net Debt Issues & $\frac{\text { Net Equity Issues }}{(5)}$ \\
\hline$I$ (Austria) x I(Post-Euro) & $\begin{array}{c}0.003 \\
(0.003)\end{array}$ & $\begin{array}{c}-0.012 * * * \\
(0.003)\end{array}$ & $\begin{array}{c}0.015^{* * *} \\
(0.002)\end{array}$ \\
\hline$I$ (Belgium) x I(Post-Euro) & $\begin{array}{c}0.003 \\
(0.003)\end{array}$ & $\begin{array}{l}-0.004 * \\
(0.002)\end{array}$ & $\begin{array}{c}0.012 * * * \\
(0.002)\end{array}$ \\
\hline$I$ (France) x $I$ (Post-Euro) & $\begin{array}{c}0.020 * * * \\
(0.003)\end{array}$ & $\begin{array}{c}0.004 \\
(0.003)\end{array}$ & $\begin{array}{c}0.015 * * * \\
(0.001)\end{array}$ \\
\hline$I($ Germany) x I(Post-Euro) & $\begin{array}{c}0.001 \\
(0.004)\end{array}$ & $\begin{array}{l}-0.004 \\
(0.003)\end{array}$ & $\begin{array}{c}0.006^{* *} \\
(0.003)\end{array}$ \\
\hline$I$ (Luxembourg) x $I$ (Post-Euro) & $\begin{array}{c}0.008 * * * \\
(0.002)\end{array}$ & $\begin{array}{c}-0.004 * * \\
(0.002)\end{array}$ & $\begin{array}{c}0.012 * * * \\
(0.001)\end{array}$ \\
\hline$I$ (Netherlands) x I(Post-Euro) & $\begin{array}{c}0.031 * * * \\
(0.003)\end{array}$ & $\begin{array}{c}0.015 * * * \\
(0.002)\end{array}$ & $\begin{array}{c}0.016 * * * \\
(0.002)\end{array}$ \\
\hline$I$ (Finland) x $I$ (Post-Euro) & $\begin{array}{c}0.034 * * * \\
(0.002)\end{array}$ & $\begin{array}{c}0.015^{* * * *} \\
(0.002)\end{array}$ & $\begin{array}{c}0.015^{* * * *} \\
(0.001)\end{array}$ \\
\hline$I$ (Ireland) x $I$ (Post-Euro) & $\begin{array}{l}-0.002 \\
(0.005)\end{array}$ & $\begin{array}{c}-0.009 * * \\
(0.003)\end{array}$ & $\begin{array}{l}0.004^{*} \\
(0.002)\end{array}$ \\
\hline$I$ (Italy) x I(Post-Euro) & $\begin{array}{c}0.045 * * * \\
(0.004)\end{array}$ & $\begin{array}{c}0.031 * * * \\
(0.003)\end{array}$ & $\begin{array}{c}0.017 * * * \\
(0.002)\end{array}$ \\
\hline$I$ (Portugal) x I(Post-Euro) & $\begin{array}{c}0.028 * * * \\
(0.006)\end{array}$ & $\begin{array}{c}0.015 * * * \\
(0.005)\end{array}$ & $\begin{array}{c}0.010 * * * \\
(0.002)\end{array}$ \\
\hline$I($ Spain) x $I$ (Post-Euro) & $\begin{array}{c}0.082 * * * \\
(0.004)\end{array}$ & $\begin{array}{c}0.047 * * * \\
(0.003)\end{array}$ & $\begin{array}{c}0.029 * * * \\
(0.001)\end{array}$ \\
\hline$I$ (Denmark) x I(Post-Euro) & $\begin{array}{c}0.027 * * * \\
(0.004)\end{array}$ & $\begin{array}{c}0.022 * * * \\
(0.003)\end{array}$ & $\begin{array}{c}0.006^{* * *} \\
(0.002)\end{array}$ \\
\hline$I$ (Norway) x $I$ (Post-Euro) & $\begin{array}{c}-0.007^{*} \\
(0.004)\end{array}$ & $\begin{array}{l}-0.005 \\
(0.003)\end{array}$ & $\begin{array}{c}0.000 \\
(0.002)\end{array}$ \\
\hline I(Sweden x I(Post-Euro) & $\begin{array}{c}0.003 \\
(0.003)\end{array}$ & $\begin{array}{l}-0.002 \\
(0.003)\end{array}$ & $\begin{array}{c}0.003^{* *} \\
(0.001)\end{array}$ \\
\hline$I$ (Switzerland) x I(Post-Euro) & $\begin{array}{c}0.001 \\
(0.004)\end{array}$ & $\begin{array}{c}-0.014 * * * \\
(0.003)\end{array}$ & $\begin{array}{c}0.014^{* * *} \\
(0.002)\end{array}$ \\
\hline Control Variables, Year Dummies, and Fixed Firm Effects & YES & YES & YES \\
\hline $\mathrm{R}^{2}$ & 0.22 & 0.16 & 0.24 \\
\hline Number of Firm-Year Observations & 29,932 & 29,932 & 29,932 \\
\hline Number of Firms & 2,486 & 2,486 & 2,486 \\
\hline
\end{tabular}




\section{Table 4}

The effect of the euro on financing activities: Results by industry groups

The table presents panel data OLS regressions estimating the effect of the introduction of the euro on corporate financing activity split by different industry groups. The sample is an unbalanced panel of firms from eleven euro countries (Austria, Belgium, Finland, France, Germany, Ireland, Italy, Luxembourg, the Netherlands, Portugal, and Spain) and five non-euro countries (Denmark, Norway, Sweden, Switzerland, and U.K.) over the time period 19912006. I(Euro Country) is an indicator variable equal to one if the firm belongs to a euro country, and is zero otherwise. Strong euro countries are the countries that are classified as having strong currencies prior to adopting the euro (i.e., Austria, Belgium, France, Germany, Luxembourg, and the Netherlands). Weak euro countries are the countries that are classified as having weak currencies prior to adopting the euro (i.e., Finland, Ireland, Italy, Portugal, and Spain). I(Post-Euro) is an indicator variable equal to one if the observation is in the post-euro time period (i.e., 1999-2006), and is zero otherwise. The industry classification is based on two-digit SIC codes, where Basic Industries = SIC codes 1-19 (Panel A), Manufacturing industries = SIC codes 20-39 (Panel B), Transportation, communications, and utilities industries = SIC codes 40-49 (Panel C), Trade industries = SIC codes 50-59(Panel D), and Services Industries = SIC codes 70-89 (Panel E). See Appendix A for other variable definitions. The same set of control variables as in Table 2 are included but not explicitly reported to conserve space. Full results are available from the authors upon request. Standard errors clustered at the country level are reported within brackets. * and **, indicates significance at the 5\%-, and 1\%-levels, respectively

\begin{tabular}{|c|c|c|c|c|c|c|}
\hline \multicolumn{7}{|l|}{ Panel A: Basic industries } \\
\hline \multirow[b]{3}{*}{ Explanatory variable: } & \multicolumn{6}{|c|}{ Dependent variable: } \\
\hline & \multicolumn{2}{|c|}{ Net External Finance } & \multicolumn{2}{|c|}{ Net Debt Issues } & \multicolumn{2}{|c|}{ Net Equity Issues } \\
\hline & $(1)$ & $(2)$ & (3) & (4) & (5) & (6) \\
\hline$I$ (Euro Country) x $I$ (Post-Euro) & $\begin{array}{c}0.056^{* *} \\
(0.019)\end{array}$ & & $\begin{array}{c}0.047 * * * \\
(0.015)\end{array}$ & & $\begin{array}{l}0.011^{* *} \\
(0.005)\end{array}$ & \\
\hline$I$ (Strong Euro Country) x I(Post-Euro) & & $\begin{array}{c}0.047 * * * \\
(0.011)\end{array}$ & & $\begin{array}{c}0.036 * * * \\
(0.010)\end{array}$ & & $\begin{array}{c}0.014 * * * \\
(0.003)\end{array}$ \\
\hline$I$ (Weak Euro Country) x I(Post-Euro) & & $\begin{array}{l}0.069 * \\
(0.035)\end{array}$ & & $\begin{array}{c}0.064 * * \\
(0.025)\end{array}$ & & $\begin{array}{c}0.007 \\
(0.008)\end{array}$ \\
\hline Control Variables, & YES & YES & YES & YES & YES & YES \\
\hline Year Dummies and Fixed Firm Effects & YES & YES & YES & YES & YES & YES \\
\hline $\mathrm{R}^{2}$ & 0.26 & 0.26 & 0.19 & 0.19 & 0.26 & 0.26 \\
\hline Number of Firm-Year Observations & 2,389 & 2,389 & 2,389 & 2,389 & 2,389 & 2,389 \\
\hline Number of Firms & 192 & 192 & 192 & 192 & 192 & 192 \\
\hline \multicolumn{7}{|l|}{ Panel B: Manufacturing industries } \\
\hline & \multicolumn{6}{|c|}{ Dependent variable: } \\
\hline & \multicolumn{2}{|c|}{ Net External Finance } & \multicolumn{2}{|c|}{ Net Debt Issues } & \multicolumn{2}{|c|}{ Net Equity Issues } \\
\hline Explanatory variable: & $(1)$ & $(2)$ & (3) & $(4)$ & (5) & (6) \\
\hline$I$ (Euro Country) x $I$ (Post-Euro) & $\begin{array}{c}0.013 \\
(0.010)\end{array}$ & & $\begin{array}{c}0.003 \\
(0.008)\end{array}$ & & $\begin{array}{c}0.009 * * \\
(0.003)\end{array}$ & \\
\hline$I$ (Strong Euro Country) x I(Post-Euro) & & $\begin{array}{c}0.004 \\
(0.009)\end{array}$ & & $\begin{array}{c}-0.003 \\
(0.008)\end{array}$ & & $\begin{array}{c}0.007 * * \\
(0.003)\end{array}$ \\
\hline$I$ (Weak Euro Country) x I(Post-Euro) & & $\begin{array}{c}0.035^{* *} \\
(0.012)\end{array}$ & & $\begin{array}{c}0.019 * * \\
(0.008)\end{array}$ & & $\begin{array}{c}0.014^{* *} \\
(0.006)\end{array}$ \\
\hline Control Variables, & YES & YES & YES & YES & YES & YES \\
\hline Year Dummies and Fixed Firm Effects & YES & YES & YES & YES & YES & YES \\
\hline $\mathrm{R}^{2}$ & 0.21 & 0.21 & 0.15 & 0.16 & 0.22 & 0.22 \\
\hline Number of Firm-Year Observations & 15,749 & 15,749 & 15,749 & 15,749 & 15,749 & 15,749 \\
\hline Number of Firms & 1,291 & 1,291 & 1,291 & 1,291 & 1,291 & 1,291 \\
\hline
\end{tabular}


Table 4 (continued)

Panel C: Transportation, communications, and utilities industries

\begin{tabular}{|c|c|c|c|c|c|c|}
\hline \multirow[b]{3}{*}{ Explanatory variable: } & \multicolumn{6}{|c|}{ Dependent variable: } \\
\hline & \multicolumn{2}{|c|}{ Net External Finance } & \multicolumn{2}{|c|}{ Net Debt Issues } & \multicolumn{2}{|c|}{ Net Equity Issues } \\
\hline & $(1)$ & $(2)$ & (3) & $(4)$ & $(5)$ & (6) \\
\hline$I$ (Euro Country) x I(Post-Euro) & $\begin{array}{c}0.025 \\
(0.017)\end{array}$ & & $\begin{array}{c}0.022 \\
(0.014)\end{array}$ & & $\begin{array}{c}0.007 \\
(0.005)\end{array}$ & \\
\hline I(Strong Euro Country) x I(Post-Euro) & & $\begin{array}{c}0.009 \\
(0.015)\end{array}$ & & $\begin{array}{c}0.005 \\
(0.013)\end{array}$ & & $\begin{array}{c}0.007 \\
(0.005)\end{array}$ \\
\hline$I$ (Weak Euro Country) x I(Post-Euro) & & $\begin{array}{c}0.048^{* *} \\
(0.018)\end{array}$ & & $\begin{array}{c}0.044^{* * *} \\
(0.013)\end{array}$ & & $\begin{array}{c}0.008 \\
(0.007)\end{array}$ \\
\hline Control Variables, & YES & YES & YES & YES & YES & YES \\
\hline Year Dummies and Fixed Firm Effects & YES & YES & YES & YES & YES & YES \\
\hline $\mathrm{R}^{2}$ & 0.19 & 0.19 & 0.16 & 0.16 & 0.23 & 0.23 \\
\hline Number of Firm-Year Observations & 3,278 & 3,278 & 3,278 & 3,278 & 3,278 & 3,278 \\
\hline Number of Firms & 274 & 274 & 274 & 274 & 274 & 274 \\
\hline \multicolumn{7}{|l|}{ Panel D: Trade industries } \\
\hline & \multicolumn{6}{|c|}{ Dependent variable: } \\
\hline & Net Exte & al Finance & Net $\mathrm{D}$ & Issues & Net Equ & y Issues \\
\hline Explanatory variable: & $(1)$ & $(2)$ & (3) & $(4)$ & $(5)$ & (6) \\
\hline$I$ (Euro Country) x I(Post-Euro) & $\begin{array}{c}0.009 \\
(0.006)\end{array}$ & & $\begin{array}{l}-0.000 \\
(0.006)\end{array}$ & & $\begin{array}{c}0.009 * * \\
(0.004)\end{array}$ & \\
\hline I(Strong Euro Country) x I(Post-Euro) & & $\begin{array}{c}0.006 \\
(0.006)\end{array}$ & & $\begin{array}{c}0.000 \\
(0.006)\end{array}$ & & $\begin{array}{c}0.006 \\
(0.005)\end{array}$ \\
\hline$I$ (Weak Euro Country) x I(Post-Euro) & & $\begin{array}{c}0.019 \\
(0.013)\end{array}$ & & $\begin{array}{l}-0.003 \\
(0.009)\end{array}$ & & $\begin{array}{c}0.020 * * * \\
(0.005)\end{array}$ \\
\hline Control Variables, & YES & YES & YES & YES & YES & YES \\
\hline Year Dummies and Fixed Firm Effects & YES & YES & YES & YES & YES & YES \\
\hline$\overline{\mathrm{R}^{2}}$ & 0.24 & 0.24 & 0.19 & 0.19 & 0.24 & 0.24 \\
\hline Number of Firm-Year Observations & 4,701 & 4,701 & 4,701 & 4,701 & 4,701 & 4,701 \\
\hline Number of Firms & 391 & 391 & 391 & 391 & 391 & 391 \\
\hline \multicolumn{7}{|l|}{ Panel E: Services industries } \\
\hline & \multicolumn{6}{|c|}{ Dependent variable: } \\
\hline & \multicolumn{2}{|c|}{ Net External Finance } & \multicolumn{2}{|c|}{ Net Debt Issues } & \multicolumn{2}{|c|}{ Net Equity Issues } \\
\hline Explanatory variable: & $(1)$ & $(2)$ & (3) & $(4)$ & $(5)$ & (6) \\
\hline$I$ (Euro Country) x I(Post-Euro) & $\begin{array}{c}0.043^{* *} \\
(0.018)\end{array}$ & & $\begin{array}{c}0.018 \\
(0.014)\end{array}$ & & $\begin{array}{c}0.021 * * * \\
(0.006)\end{array}$ & \\
\hline$I$ (Strong Euro Country) x I(Post-Euro) & & $\begin{array}{c}0.029 \\
(0.019)\end{array}$ & & $\begin{array}{c}0.003 \\
(0.012)\end{array}$ & & $\begin{array}{c}0.022^{* * *} \\
(0.007)\end{array}$ \\
\hline$I$ (Weak Euro Country) x I(Post-Euro) & & $\begin{array}{c}0.079 * * * \\
(0.022)\end{array}$ & & $\begin{array}{c}0.054 * * * \\
(0.017)\end{array}$ & & $\begin{array}{l}0.019 * \\
(0.010)\end{array}$ \\
\hline Control Variables, & YES & YES & YES & YES & YES & YES \\
\hline Year Dummies and Fixed Firm Effects & YES & YES & YES & YES & YES & YES \\
\hline $\mathrm{R}^{2}$ & 0.24 & 0.24 & 0.15 & 0.15 & 0.26 & 0.26 \\
\hline Number of Firm-Year Observations & 3,794 & 3,794 & 3,794 & 3,794 & 3,794 & 3,794 \\
\hline Number of Firms & 336 & 336 & 336 & 336 & 336 & 336 \\
\hline
\end{tabular}




\section{Table 5}

External finance dependence and the effect of the euro on financing activities

The table presents panel data OLS regressions estimating the effect of the introduction of the euro on corporate financing activity split by external finance dependence. The sample is an unbalanced panel of firms from eleven euro countries (Austria, Belgium, Finland, France, Germany, Ireland, Italy, Luxembourg, the Netherlands, Portugal, and Spain) and five non-euro countries (Denmark, Norway, Sweden, Switzerland, and U.K.) over the time period 1991-2006. I(Euro Country) is an indicator variable equal to one if the firm belongs to a euro country, and is zero otherwise. Strong euro countries are the countries that are classified as having strong currencies prior to adopting the euro (i.e., Austria, Belgium, France, Germany, Luxembourg, and the Netherlands). Weak euro countries are the countries that are classified as having weak currencies prior to adopting the euro (i.e., Finland, Ireland, Italy, Portugal, and Spain). I(Post-Euro) is an indicator variable equal to one if the observation is in the post-euro time period (i.e., 1999-2006), and is zero otherwise. Panel A presents results for firm in more external finance dependent industries, and Panel B presents results for firms in less external finance dependent industries. Following Rajan and Zingales (1998), external finance dependence is defined as the average fraction of capital expenditures not financed with internal funds for U.S. firms in the same industry during 1991-1997. An industry (and consequently any firm in this industry) is then classified as more external finance dependent if its industry has a higher external finance dependence than the median industry represented in the sample. See Appendix A for other variable definitions. The same set of control variables as in Table 2 are included but not explicitly reported to conserve space. Full results are available from the authors upon request. Standard errors clustered at the country level are reported within brackets. * and **, indicates significance at the 5\%-, and 1\%-levels, respectively

\begin{tabular}{|c|c|c|c|c|c|c|}
\hline \multicolumn{7}{|c|}{ Panel A: More external finance dependent industries } \\
\hline \multirow[b]{3}{*}{ Explanatory variable: } & \multicolumn{6}{|c|}{ Dependent variable: } \\
\hline & \multicolumn{2}{|c|}{ Net External Finance } & \multicolumn{2}{|c|}{ Net Debt Issues } & \multicolumn{2}{|c|}{ Net Equity Issues } \\
\hline & (1) & (2) & (3) & (4) & (5) & (6) \\
\hline$I$ (Euro Country) x $I$ (Post-Euro) & $\begin{array}{c}0.027 * * \\
(0.011)\end{array}$ & & $\begin{array}{l}0.016^{*} \\
(0.009)\end{array}$ & & $\begin{array}{c}0.011^{* *} \\
(0.004)\end{array}$ & \\
\hline I(Strong Euro Country) x I(Post-Euro) & & $\begin{array}{l}0.016^{*} \\
(0.009)\end{array}$ & & $\begin{array}{c}0.007 \\
(0.006)\end{array}$ & & $\begin{array}{l}0.009 * \\
(0.005)\end{array}$ \\
\hline$I$ (Weak Euro Country) x I(Post-Euro) & & $\begin{array}{c}0.056^{* *} \\
(0.020)\end{array}$ & & $\begin{array}{c}0.039 * * * \\
(0.013)\end{array}$ & & $\begin{array}{c}0.016^{* *} \\
(0.007)\end{array}$ \\
\hline Control Variables, & YES & YES & YES & YES & YES & YES \\
\hline Year Dummies and Fixed Firm Effects & YES & YES & YES & YES & YES & YES \\
\hline $\mathrm{R}^{2}$ & 0.23 & 0.23 & 0.16 & 0.16 & 0.26 & 0.26 \\
\hline Number of Firm-Year Observations & 14,574 & 14,574 & 14,574 & 14,574 & 14,574 & 14,574 \\
\hline Number of Firms & 1,232 & 1,232 & 1,232 & 1,232 & 1,232 & 1,232 \\
\hline \multicolumn{7}{|c|}{ Panel B: Less external finance dependent industries } \\
\hline & \multicolumn{6}{|c|}{ Dependent variable: } \\
\hline & \multicolumn{2}{|c|}{ Net External Finance } & \multicolumn{2}{|c|}{ Net Debt Issues } & \multicolumn{2}{|c|}{ Net Equity Issues } \\
\hline Explanatory variable: & $(1)$ & $(2)$ & (3) & (4) & $(5)$ & (6) \\
\hline$I$ (Euro Country) x $I$ (Post-Euro) & $\begin{array}{c}0.013 \\
(0.009)\end{array}$ & & $\begin{array}{c}0.004 \\
(0.007)\end{array}$ & & $\begin{array}{c}0.009 * * * \\
(0.003)\end{array}$ & \\
\hline I(Strong Euro Country) x I(Post-Euro) & & $\begin{array}{c}0.004 \\
(0.008)\end{array}$ & & $\begin{array}{c}-0.003 \\
(0.006)\end{array}$ & & $\begin{array}{c}0.007 * * \\
(0.003)\end{array}$ \\
\hline$I$ (Weak Euro Country) x I(Post-Euro) & & $\begin{array}{c}0.033 * * * \\
(0.008)\end{array}$ & & $\begin{array}{c}0.019 * * \\
(0.007)\end{array}$ & & $\begin{array}{c}0.012 * * * \\
(0.003)\end{array}$ \\
\hline Control Variables, & YES & YES & YES & YES & YES & YES \\
\hline Year Dummies and Fixed Firm Effects & YES & YES & YES & YES & YES & YES \\
\hline$\overline{\mathrm{R}^{2}}$ & 0.26 & 0.26 & 0.23 & 0.23 & 0.21 & 0.21 \\
\hline Number of Firm-Year Observations & 15,358 & 15,358 & 15,358 & 15,358 & 15,358 & 15,358 \\
\hline Number of Firms & 1,254 & 1,254 & 1,254 & 1,254 & 1,254 & 1,254 \\
\hline
\end{tabular}


Table 6

Firm Size and the Effect of the Euro on Financing Activities

The table presents panel data OLS regressions estimating the effect of the introduction of the euro on corporate financing activity split by firm size. The sample is an unbalanced panel of firms from eleven euro countries (Austria, Belgium, Finland, France, Germany, Ireland, Italy, Luxembourg, the Netherlands, Portugal, and Spain) and five non-euro countries (Denmark, Norway, Sweden, Switzerland, and U.K.) over the time period 1991-2006. I(Euro Country) is an indicator variable equal to one if the firm belongs to a euro country, and is zero otherwise. Strong euro countries are the countries that are classified as having strong currencies prior to adopting the euro (i.e., Austria, Belgium, France, Germany, Luxembourg, and the Netherlands). Weak euro countries are the countries that are classified as having weak currencies prior to adopting the euro (i.e., Finland, Ireland, Italy, Portugal, and Spain). $I$ (Post-Euro) is an indicator variable equal to one if the observation is in the post-euro time period (i.e., 1999-2006), and is zero otherwise. Firms are classified into large and small firms based on the following: (i) First we calculate each individual firm's average sales in inflation-adjusted USD in the time period 1991-1997. (ii) Second, we classify a firm as large if this average is above the corresponding median for all sample firms; otherwise it is classified as small. Panel A presents results for large firms and Panel B present results for small firms. The same set of control variables as in Table 2 are included but not explicitly reported to conserve space. See Appendix A for variable definitions. Standard errors clustered at the country level are reported within brackets. * and **, indicates significance at the 5\%-, and $1 \%$-levels, respectively

\begin{tabular}{|c|c|c|c|c|c|c|}
\hline \multicolumn{7}{|l|}{ Panel A: Large firms } \\
\hline \multirow[b]{3}{*}{ Explanatory variable: } & \multicolumn{6}{|c|}{ Dependent variable: } \\
\hline & \multicolumn{2}{|c|}{ Net External Finance } & \multicolumn{2}{|c|}{ Net Debt Issues } & \multicolumn{2}{|c|}{ Net Equity Issues } \\
\hline & $(1)$ & $(2)$ & (3) & (4) & (5) & (6) \\
\hline$I$ (Euro Country) x I(Post-Euro) & $\begin{array}{c}0.025^{* *} \\
(0.009)\end{array}$ & & $\begin{array}{l}0.014^{*} \\
(0.008)\end{array}$ & & $\begin{array}{l}0.011 * * \\
(0.004)\end{array}$ & \\
\hline I(Strong Euro Country) x I(Post-Euro) & & $\begin{array}{c}0.015^{* *} \\
(0.006)\end{array}$ & & $\begin{array}{c}0.006 \\
(0.005)\end{array}$ & & $\begin{array}{c}0.009 * * \\
(0.004)\end{array}$ \\
\hline$I$ (Weak Euro Country) x I(Post-Euro) & & $\begin{array}{c}0.050^{* * * *} \\
(0.012)\end{array}$ & & $\begin{array}{c}0.032 * * * \\
(0.010)\end{array}$ & & $\begin{array}{c}0.016^{* * *} \\
(0.005)\end{array}$ \\
\hline Control Variables, & YES & YES & YES & YES & YES & YES \\
\hline Year Dummies and Fixed Firm Effects & YES & YES & YES & YES & YES & YES \\
\hline$\overline{\mathrm{R}^{2}}$ & 0.21 & 0.21 & 0.18 & 0.18 & 0.20 & 0.20 \\
\hline Number of Firm-Year Observations & 15,782 & 15,782 & 15,782 & 15,782 & 15,782 & 15,782 \\
\hline Number of Firms & 1,243 & 1,243 & 1,243 & 1,243 & 1,243 & 1,243 \\
\hline \multicolumn{7}{|l|}{ Panel B: Small firms } \\
\hline & \multicolumn{6}{|c|}{ Dependent variable: } \\
\hline & \multicolumn{2}{|c|}{ Net External Finance } & \multicolumn{2}{|c|}{ Net Debt Issues } & \multicolumn{2}{|c|}{ Net Equity Issues } \\
\hline Explanatory variable: & $(1)$ & $(2)$ & (3) & (4) & (5) & (6) \\
\hline$I$ (Euro Country) x I(Post-Euro) & $\begin{array}{c}0.013 \\
(0.011)\end{array}$ & & $\begin{array}{c}0.005 \\
(0.008)\end{array}$ & & $\begin{array}{l}0.008^{* *} \\
(0.003)\end{array}$ & \\
\hline I(Strong Euro Country) x I(Post-Euro) & & $\begin{array}{c}0.004 \\
(0.010)\end{array}$ & & $\begin{array}{c}-0.002 \\
(0.007)\end{array}$ & & $\begin{array}{l}0.007^{*} \\
(0.003)\end{array}$ \\
\hline$I$ (Weak Euro Country) x I(Post-Euro) & & $\begin{array}{c}0.035^{* *} \\
(0.014)\end{array}$ & & $\begin{array}{c}0.022^{* *} \\
(0.009)\end{array}$ & & $\begin{array}{l}0.011^{*} \\
(0.006)\end{array}$ \\
\hline Control Variables, & YES & YES & YES & YES & YES & YES \\
\hline Year Dummies and Fixed Firm Effects & YES & YES & YES & YES & YES & YES \\
\hline $\mathrm{R}^{2}$ & 0.23 & 0.23 & 0.15 & 0.15 & 0.26 & 0.26 \\
\hline Number of Firm-Year Observations & 14,150 & 14,150 & 14,150 & 14,150 & 14,150 & 14,150 \\
\hline Number of Firms & 1,243 & 1,243 & 1,243 & 1,243 & 1,243 & 1,243 \\
\hline
\end{tabular}




\section{Table 7}

The effect of the euro on financing activities: Early versus later time period effects

The table presents panel data OLS regressions estimating the effect of the introduction of the euro on corporate financing activity split by external finance dependence. The sample is an unbalanced panel of firms from eleven euro countries (Austria, Belgium, Finland, France, Germany, Ireland, Italy, Luxembourg, the Netherlands, Portugal, and Spain) and five non-euro countries (Denmark, Norway, Sweden, Switzerland, and U.K.) over the time period 1991-2006. I(Euro Country) is an indicator variable equal to one if the firm belongs to a euro country, and is zero otherwise. Strong euro countries are the countries that are classified as having strong currencies prior to adopting the euro (i.e., Austria, Belgium, France, Germany, Luxembourg, and the Netherlands). Weak euro countries are the countries that are classified as having weak currencies prior to adopting the euro (i.e., Finland, Ireland, Italy, Portugal, and Spain). To gauge whether the impact of the euro on financing activities is transitory or more long-term, the post-euro time period is broken up in two time periods: $1999-2002$ versus 2003-2006. I(Post-Euro,1999-2002) and I(Post-Euro, 2003-2006) are the dummy variable indicators for these respective time periods. The same set of control variables as in Table 2 are included but not explicitly reported to conserve space. Full results are available from the authors upon request. See Appendix A for other variable definitions. Standard errors clustered at the country level are reported within brackets. * and **, indicates significance at the 5\%-, and $1 \%$ levels, respectively.

\begin{tabular}{|c|c|c|c|c|c|c|}
\hline \multirow[b]{3}{*}{ Explanatory variable: } & \multicolumn{6}{|c|}{ Dependent variable: } \\
\hline & \multicolumn{2}{|c|}{ Net External Finance } & \multicolumn{2}{|c|}{ Net Debt Issues } & \multicolumn{2}{|c|}{ Net Equity Issues } \\
\hline & $(1)$ & $(2)$ & $(3)$ & $(4)$ & (5) & $(6)$ \\
\hline$I$ (Euro Country) x I(Post-Euro,1999-2002) & $\begin{array}{c}0.005 \\
(0.009)\end{array}$ & & $\begin{array}{c}0.000 \\
(0.007)\end{array}$ & & $\begin{array}{c}0.006 \\
(0.004)\end{array}$ & \\
\hline I(Euro Country) x I(Post-Euro, 2003-2006) & $\begin{array}{c}0.039 * * * \\
(0.012)\end{array}$ & & $\begin{array}{c}0.020 * * \\
(0.008)\end{array}$ & & $\begin{array}{c}0.017^{* * *} \\
(0.004)\end{array}$ & \\
\hline I(Strong Euro Country) x I(Post-Euro, 1999-2002) & & $\begin{array}{c}-0.002 \\
(0.009)\end{array}$ & & $\begin{array}{c}-0.006 \\
(0.006)\end{array}$ & & $\begin{array}{c}0.005 \\
(0.004)\end{array}$ \\
\hline I(Strong Euro Country) x I(Post-Euro, 2003-2006) & & $\begin{array}{c}0.026 * * * \\
(0.007)\end{array}$ & & $\begin{array}{l}0.011^{*} \\
(0.006)\end{array}$ & & $\begin{array}{c}0.013 * * * \\
(0.003)\end{array}$ \\
\hline I(Weak Euro Country) x I(Post-Euro, 1999-2002) & & $\begin{array}{c}0.023^{* *} \\
(0.010)\end{array}$ & & $\begin{array}{c}0.016 \\
(0.009)\end{array}$ & & $\begin{array}{c}0.007 * * \\
(0.003)\end{array}$ \\
\hline I(Weak Euro Country) x I(Post-Euro, 2003-2006) & & $\begin{array}{c}0.069 * * * \\
(0.017)\end{array}$ & & $\begin{array}{c}0.040^{* * *} \\
(0.010)\end{array}$ & & $\begin{array}{c}0.024^{* * *} \\
(0.008)\end{array}$ \\
\hline Control Variables & YES & YES & YES & YES & YES & YES \\
\hline Year Dummies and Fixed Firm Effects & YES & YES & YES & YES & YES & YES \\
\hline $\mathrm{R}^{2}$ & 0.22 & 0.22 & 0.16 & 0.16 & 0.24 & 0.24 \\
\hline Number of Firm-Year Observations & 29,932 & 29,932 & 29,932 & 29,932 & 29,932 & 29,932 \\
\hline Number of Firms & 2,486 & 2,486 & 2,486 & 2,486 & 2,486 & 2,486 \\
\hline
\end{tabular}




\section{Table 8}

The effect of the euro on financing activities: The impact of transposition of FSAP directives

The table presents panel data OLS regressions estimating the effect of the introduction of the euro on corporate financing activity. The sample is an unbalanced panel of firms from eleven euro countries (Austria, Belgium, Finland, France, Germany, Ireland, Italy, Luxembourg, the Netherlands, Portugal, and Spain) and five non-euro countries (Denmark, Norway, Sweden, Switzerland, and U.K.) over the time period 1991-2006. I(Euro Country) is an indicator variable equal to one if the firm belongs to a euro country, and is zero otherwise. Strong euro countries are the countries that are classified as having strong currencies prior to adopting the euro (i.e., Austria, Belgium, France, Germany, Luxembourg, and the Netherlands). Weak euro countries are the countries that are classified as having weak currencies prior to adopting the euro (i.e., Finland, Ireland, Italy, Portugal, and Spain). I(Post-Euro) is an indicator variable equal to one if the observation is in the post-euro time period (i.e., 1999-2006), and is zero otherwise. To gauge whether the impact of the euro on financing activities is related to the transposition of FSAP directives among EU member countries we include the variable FSAP index; defined as log(1+cumulative directive transpositions at year $t$ for country $i$ ). This variable will have a value of zero for the non-EU members (i.e., Norway and Switzerland). We only consider FSAP directives related to banking and securities markets. This variable is lagged one year relative to the dependent variables. The data on the timing on individual countries transposition of FSAP directives is from Kalemli-Ozcan, Papaioannou, and Peydró (2010). The same set of control variables as in Table 2 are included but no explicitly reported to conserve space. Full results are available from the authors upon request. See Appendix A for other variable definitions. Standard errors clustered at the country level are reported within brackets. * and **, indicates significance at the 5\%-, and 1\%-levels, respectively.

\begin{tabular}{|c|c|c|c|c|c|c|c|c|c|c|c|c|}
\hline \multirow[b]{3}{*}{ Explanatory variable: } & \multicolumn{12}{|c|}{ Dependent variable: } \\
\hline & \multicolumn{4}{|c|}{ Net External Finance } & \multicolumn{4}{|c|}{ Net Debt Issues } & \multicolumn{4}{|c|}{ Net Equity Issues } \\
\hline & (1) & $(2)$ & (3) & (4) & (5) & (6) & (7) & (8) & (9) & $(10)$ & (11) & (12) \\
\hline$I$ (Euro Country) x I(Post-Euro) & $\begin{array}{l}0.017 * \\
(0.009)\end{array}$ & & $\begin{array}{c}0.010 \\
(0.009)\end{array}$ & & $\begin{array}{c}0.007 \\
(0.007)\end{array}$ & & $\begin{array}{c}0.004 \\
(0.007)\end{array}$ & & $\begin{array}{c}0.009 * * \\
(0.003)\end{array}$ & & $\begin{array}{c}0.007^{* *} \\
(0.003)\end{array}$ & \\
\hline I(Strong Euro Country) x I(Post-Euro) & & $\begin{array}{c}0.007 \\
(0.007)\end{array}$ & & $\begin{array}{c}0.001 \\
(0.008)\end{array}$ & & $\begin{array}{c}-0.000 \\
(0.005)\end{array}$ & & $\begin{array}{c}-0.004 \\
(0.006)\end{array}$ & & $\begin{array}{c}0.008^{* *} \\
(0.003)\end{array}$ & & $\begin{array}{c}0.006 \\
(0.004)\end{array}$ \\
\hline$I$ (Weak Euro Country) x I(Post-Euro) & & $\begin{array}{c}0.040 * * * \\
(0.011)\end{array}$ & & $\begin{array}{c}0.034 * * * \\
(0.010)\end{array}$ & & $\begin{array}{c}0.024 * * * \\
(0.008)\end{array}$ & & $\begin{array}{c}0.021 * * \\
(0.008)\end{array}$ & & $\begin{array}{c}0.014 * * * \\
(0.004)\end{array}$ & & $\begin{array}{c}0.012 * * * \\
(0.004)\end{array}$ \\
\hline$I$ (Euro Country) x I(Post-Euro) x FSAP Index & & & $\begin{array}{c}0.013^{* * * *} \\
(0.004)\end{array}$ & $\begin{array}{c}0.013 * * * \\
(0.003)\end{array}$ & & & $\begin{array}{c}0.007 * * \\
(0.003)\end{array}$ & $\begin{array}{c}0.007^{* *} \\
(0.002)\end{array}$ & & & $\begin{array}{c}0.004^{* *} \\
(0.002)\end{array}$ & $\begin{array}{c}0.004^{* *} \\
(0.002)\end{array}$ \\
\hline FSAP Index & $\begin{array}{c}0.009 \\
(0.008)\end{array}$ & $\begin{array}{c}0.010 \\
(0.008)\end{array}$ & $\begin{array}{c}0.000 \\
(0.008)\end{array}$ & $\begin{array}{c}0.001 \\
(0.008)\end{array}$ & $\begin{array}{c}0.006 \\
(0.007)\end{array}$ & $\begin{array}{c}0.006 \\
(0.007)\end{array}$ & $\begin{array}{c}0.001 \\
(0.008)\end{array}$ & $\begin{array}{c}0.002 \\
(0.008)\end{array}$ & $\begin{array}{c}0.003 \\
(0.003)\end{array}$ & $\begin{array}{c}0.003 \\
(0.003)\end{array}$ & $\begin{array}{c}0.001 \\
(0.002)\end{array}$ & $\begin{array}{c}0.001 \\
(0.002)\end{array}$ \\
\hline Control Variables & YES & YES & YES & YES & \& YES & YES & YES & YES & YES & YES & YES & YES \\
\hline Year Dummies and Fixed Firm Effects & YES & YES & YES & YES & $\delta \quad$ YES & YES & YES & YES & YES & YES & YES & YES \\
\hline $\mathrm{R}^{2}$ & 0.22 & 0.22 & 0.22 & 0.22 & 0.16 & 0.16 & 0.16 & 0.16 & 0.24 & 0.24 & 0.24 & 0.24 \\
\hline Number of Firm-Year Observations & 29,932 & 29,932 & 29,932 & 29,932 & 29,932 & 29,932 & 29,932 & 29,932 & 29,932 & 29,932 & 29,932 & 29,932 \\
\hline Number of Firms & 2,486 & 2,486 & 2,486 & 2,486 & 2,486 & 2,486 & 2,486 & 2,486 & 2,486 & 2,486 & 2,486 & 2,486 \\
\hline
\end{tabular}




\section{Table 9}

The effect of the euro on asset growth and corporate payout.

The table presents panel data OLS regressions estimating the effect of the introduction of the euro on asset growth and corporate payout. The sample is an unbalanced panel of firms from eleven euro countries (Austria, Belgium, Finland, France, Germany, Ireland, Italy, Luxembourg, the Netherlands, Portugal, and Spain) and five non-euro countries (Denmark, Norway, Sweden, Switzerland, and U.K.) over the time period 1991-2006. I(Euro Country) is an indicator variable equal to one if the firm belongs to a euro country, and is zero otherwise. Strong euro countries are the countries that are classified as having strong currencies prior to adopting the euro (i.e., Austria, Belgium, France, Germany, Luxembourg, and the Netherlands). Weak euro countries are the countries that are classified as having weak currencies prior to adopting the euro (i.e., Finland, Ireland, Italy, Portugal, and Spain). I(Post-Euro) is an indicator variable equal to one if the observation is in the post-euro time period (i.e., 1999-2006), and is zero otherwise. Panel A presents results for the full sample. In Panels B and C the sample is split based on external finance dependence, where Panel B presents results for firm in more external finance dependent industries and Panel C presents results for firms in less external finance dependent industries. Following Rajan and Zingales (1998), external finance dependence is defined as the average fraction of capital expenditures not financed with internal funds for U.S. firms in the same industry during 1991-1997. An industry (and consequently any firm in this industry) is then classified as more external finance dependent if its industry has a higher external finance dependence than the median industry represented in the sample. Panel D estimate the effects of the euro separately for the early (1999-2002) and later (2003-2006) post-euro time periods. For Panels B - D the same set of control variables as in Panel A are included but not explicitly reported to conserve space. See Appendix A for variable definitions. Standard errors clustered at the country level are reported within brackets. * and **, indicates significance at the 5\%-, and 1\%-levels, respectively. 
Table 9 (continued)

\begin{tabular}{|c|c|c|c|c|c|c|c|c|c|c|}
\hline \multicolumn{11}{|l|}{ Panel A: Full sample } \\
\hline \multirow[b]{3}{*}{ Explanatory variable: } & \multicolumn{10}{|c|}{ Dependent variable: } \\
\hline & \multicolumn{2}{|c|}{ Change in Total Assets } & \multicolumn{2}{|c|}{$\begin{array}{c}\text { Change in Non-Cash } \\
\text { Assets }\end{array}$} & \multicolumn{2}{|c|}{$\begin{array}{l}\text { Change in Cash } \\
\text { Holdings }\end{array}$} & \multicolumn{2}{|c|}{ Dividends } & \multicolumn{2}{|c|}{ Total Payout } \\
\hline & $(1)$ & $(2)$ & (3) & $(4)$ & $(5)$ & $(6)$ & $(7)$ & $(8)$ & (9) & $(10)$ \\
\hline$I$ (Euro Country) x I(Post-Euro) & $\begin{array}{l}0.037^{*} \\
(0.018)\end{array}$ & & $\begin{array}{l}0.038^{* *} \\
(0.018)\end{array}$ & & $\begin{array}{l}-0.000 \\
(0.003)\end{array}$ & & $\begin{array}{c}0.002 \\
(0.003)\end{array}$ & & $\begin{array}{c}0.001 \\
(0.004)\end{array}$ & \\
\hline I(Strong Euro Country) x I(Post-Euro) & & $\begin{array}{c}0.023 \\
(0.017)\end{array}$ & & $\begin{array}{c}0.025 \\
(0.016)\end{array}$ & & $\begin{array}{l}-0.001 \\
(0.003)\end{array}$ & & $\begin{array}{c}0.001 \\
(0.003)\end{array}$ & & $\begin{array}{l}-0.001 \\
(0.003)\end{array}$ \\
\hline$I$ (Weak Euro Country) x I(Post-Euro) & & $\begin{array}{c}0.071^{* * *} \\
(0.023)\end{array}$ & & $\begin{array}{c}0.070 * * * \\
(0.020)\end{array}$ & & $\begin{array}{c}0.002 \\
(0.005)\end{array}$ & & $\begin{array}{c}0.005 \\
(0.004)\end{array}$ & & $\begin{array}{c}0.003 \\
(0.006)\end{array}$ \\
\hline U.S. Industry Q & $\begin{array}{c}0.090 * * * \\
(0.010)\end{array}$ & $\begin{array}{c}0.090 * * * \\
(0.010)\end{array}$ & $\begin{array}{c}0.068 * * * \\
(0.008)\end{array}$ & $\begin{array}{c}0.068 * * * \\
(0.008)\end{array}$ & $\begin{array}{c}0.015^{* * *} \\
(0.003)\end{array}$ & $\begin{array}{c}0.015 * * * \\
(0.003)\end{array}$ & $\begin{array}{c}0.001^{* *} \\
(0.000)\end{array}$ & $\begin{array}{c}0.001 * * \\
(0.000)\end{array}$ & $\begin{array}{c}0.000 \\
(0.000)\end{array}$ & $\begin{array}{c}0.000 \\
(0.000)\end{array}$ \\
\hline Log(Sales) & $\begin{array}{c}-0.116^{* * *} \\
(0.007)\end{array}$ & $\begin{array}{c}-0.117^{* * *} \\
(0.006)\end{array}$ & $\begin{array}{c}-0.103^{* * *} \\
(0.007)\end{array}$ & $\begin{array}{c}-0.104^{* * *} \\
(0.007)\end{array}$ & $\begin{array}{c}-0.013^{* * *} \\
(0.002)\end{array}$ & $\begin{array}{c}-0.013^{* * *} \\
(0.002)\end{array}$ & $\begin{array}{c}-0.002 * * * \\
(0.001)\end{array}$ & $\begin{array}{c}-0.002^{* * * *} \\
(0.001)\end{array}$ & $\begin{array}{c}-0.002 * * * \\
(0.001)\end{array}$ & $\begin{array}{c}-0.002 * * * \\
(0.001)\end{array}$ \\
\hline EBITDA/Assets & $\begin{array}{c}0.656 * * * \\
(0.036)\end{array}$ & $\begin{array}{c}0.655^{* * * *} \\
(0.035)\end{array}$ & $\begin{array}{c}0.640^{* * *} \\
(0.038)\end{array}$ & $\begin{array}{c}0.639 * * * \\
(0.037)\end{array}$ & $\begin{array}{c}0.022 \\
(0.015)\end{array}$ & $\begin{array}{c}0.022 \\
(0.015)\end{array}$ & $\begin{array}{c}0.078 * * * \\
(0.005)\end{array}$ & $\begin{array}{c}0.078 * * * \\
(0.005)\end{array}$ & $\begin{array}{c}0.090 * * * \\
(0.007)\end{array}$ & $\begin{array}{c}0.090 * * * \\
(0.007)\end{array}$ \\
\hline Collateral/Assets & $\begin{array}{c}0.020 \\
(0.024)\end{array}$ & $\begin{array}{c}0.018 \\
(0.025)\end{array}$ & $\begin{array}{l}-0.102 * * * \\
(0.025)\end{array}$ & $\begin{array}{c}-0.104 * * * \\
(0.025)\end{array}$ & $\begin{array}{c}0.103^{* * *} \\
(0.018)\end{array}$ & $\begin{array}{c}0.103 * * * \\
(0.018)\end{array}$ & $\begin{array}{c}-0.010^{* * *} \\
(0.003)\end{array}$ & $\begin{array}{c}-0.010^{* * *} \\
(0.003)\end{array}$ & $\begin{array}{l}-0.015^{* * *} \\
(0.004)\end{array}$ & $\begin{array}{c}-0.015^{* * *} \\
(0.004)\end{array}$ \\
\hline$I($ Leverage> $>90 \%)$ & $\begin{array}{l}-0.038 \\
(0.034)\end{array}$ & $\begin{array}{l}-0.038 \\
(0.034)\end{array}$ & $\begin{array}{c}-0.032 \\
(0.036)\end{array}$ & $\begin{array}{c}-0.032 \\
(0.036)\end{array}$ & $\begin{array}{c}-0.003 \\
(0.003)\end{array}$ & $\begin{array}{c}-0.003 \\
(0.003)\end{array}$ & $\begin{array}{l}-0.001 \\
(0.001)\end{array}$ & $\begin{array}{c}-0.001 \\
(0.001)\end{array}$ & $\begin{array}{c}-0.000 \\
(0.001)\end{array}$ & $\begin{array}{c}-0.000 \\
(0.001)\end{array}$ \\
\hline GDP Growth & $\begin{array}{c}1.626 * * * \\
(0.307)\end{array}$ & $\begin{array}{c}1.557 * * * \\
(0.287)\end{array}$ & $\begin{array}{c}1.658 * * * \\
(0.292)\end{array}$ & $\begin{array}{c}1.594 * * * \\
(0.274)\end{array}$ & $\begin{array}{l}-0.027 \\
(0.046)\end{array}$ & $\begin{array}{c}-0.031 \\
(0.045)\end{array}$ & $\begin{array}{c}0.071 \\
(0.041)\end{array}$ & $\begin{array}{l}0.066^{*} \\
(0.036)\end{array}$ & $\begin{array}{c}0.057 \\
(0.060)\end{array}$ & $\begin{array}{c}0.053 \\
(0.054)\end{array}$ \\
\hline Term Spread & $\begin{array}{c}-1.527^{* *} \\
(0.524)\end{array}$ & $\begin{array}{c}-1.551^{* *} \\
(0.529)\end{array}$ & $\begin{array}{c}-1.402^{* * *} \\
(0.476)\end{array}$ & $\begin{array}{c}-1.425^{* * *} \\
(0.480)\end{array}$ & $\begin{array}{c}-0.064 \\
(0.092)\end{array}$ & $\begin{array}{c}-0.065 \\
(0.092)\end{array}$ & $\begin{array}{c}-0.054 \\
(0.047)\end{array}$ & $\begin{array}{c}-0.055 \\
(0.044)\end{array}$ & $\begin{array}{c}-0.027 \\
(0.060)\end{array}$ & $\begin{array}{l}-0.028 \\
(0.058)\end{array}$ \\
\hline Change in USD Exchange Rate & $\begin{array}{c}-0.294 * * * \\
(0.070)\end{array}$ & $\begin{array}{c}-0.307 * * * \\
(0.074)\end{array}$ & $\begin{array}{c}-0.303^{* * *} \\
(0.060)\end{array}$ & $\begin{array}{c}-0.316^{* * *} \\
(0.063)\end{array}$ & $\begin{array}{c}-0.004 \\
(0.013)\end{array}$ & $\begin{array}{c}-0.004 \\
(0.013)\end{array}$ & $\begin{array}{c}-0.002 \\
(0.002)\end{array}$ & $\begin{array}{c}-0.003 \\
(0.003)\end{array}$ & $\begin{array}{c}-0.004 \\
(0.004)\end{array}$ & $\begin{array}{c}-0.005 \\
(0.004)\end{array}$ \\
\hline Year Dummies and Fixed Firm Effects & YES & YES & YES & YES & YES & YES & YES & YES & YES & YES \\
\hline $\mathrm{R}^{2}$ & 0.299 & 0.300 & 0.299 & 0.299 & 0.100 & 0.100 & 0.656 & 0.656 & 0.555 & 0.555 \\
\hline Number of Firm-Year Observations & 29,932 & 29,932 & 29,809 & 29,809 & 29,809 & 29,809 & 29,357 & 29,357 & 23,901 & 23,901 \\
\hline Number of Firms & 2,486 & 2,486 & 2,477 & 2,477 & 2,477 & 2,477 & 2,472 & 2,472 & 2,276 & 2,276 \\
\hline
\end{tabular}


Table 9 (continued)

Panel B: More external finance dependent industries

\begin{tabular}{|c|c|c|c|c|c|c|c|c|c|c|}
\hline \multirow[b]{3}{*}{ Explanatory variable: } & \multicolumn{10}{|c|}{ Dependent variable: } \\
\hline & \multicolumn{2}{|c|}{ Change in Total Assets } & \multicolumn{2}{|c|}{$\begin{array}{c}\text { Change in Non-Cash } \\
\text { Assets }\end{array}$} & \multicolumn{2}{|c|}{$\begin{array}{l}\text { Change in Cash } \\
\text { Holdings }\end{array}$} & \multicolumn{2}{|c|}{ Dividends } & \multicolumn{2}{|c|}{ Total Payout } \\
\hline & $(1)$ & $(2)$ & (3) & $(4)$ & (5) & $(6)$ & (7) & $(8)$ & (9) & $(10)$ \\
\hline$I$ (Euro Country) x I(Post-Euro) & $\begin{array}{l}0.050^{* *} \\
(0.020)\end{array}$ & & $\begin{array}{l}0.052 * * \\
(0.018)\end{array}$ & & $\begin{array}{l}-0.000 \\
(0.004)\end{array}$ & & $\begin{array}{c}0.002 \\
(0.003)\end{array}$ & & $\begin{array}{c}0.001 \\
(0.004)\end{array}$ & \\
\hline I(Strong Euro Country) x I(Post-Euro) & & $\begin{array}{c}0.031 \\
(0.018)\end{array}$ & & $\begin{array}{c}0.035^{* *} \\
(0.016)\end{array}$ & & $\begin{array}{l}-0.001 \\
(0.004)\end{array}$ & & $\begin{array}{c}0.001 \\
(0.003)\end{array}$ & & $\begin{array}{l}-0.001 \\
(0.003)\end{array}$ \\
\hline$I$ (Weak Euro Country) x I(Post-Euro) & & $\begin{array}{c}0.099 * * * \\
(0.027)\end{array}$ & & $\begin{array}{c}0.099 * * * \\
(0.022)\end{array}$ & & $\begin{array}{c}0.002 \\
(0.006)\end{array}$ & & $\begin{array}{c}0.005 \\
(0.005)\end{array}$ & & $\begin{array}{c}0.004 \\
(0.006)\end{array}$ \\
\hline Control Variables & YES & YES & YES & YES & YES & YES & YES & YES & YES & YES \\
\hline Year Dummies and Fixed Firm Effects & YES & YES & YES & YES & YES & YES & YES & YES & YES & YES \\
\hline $\mathrm{R}^{2}$ & 0.30 & 0.30 & 0.300 & 0.30 & 0.10 & 0.10 & 0.67 & 0.67 & 0.57 & 0.57 \\
\hline Number of Firm-Year Observations & 14,574 & 14,574 & 14,481 & 14,481 & 14,481 & 14,481 & 14,301 & 14,301 & 11,848 & 11,848 \\
\hline Number of Firms & 1,232 & 1,232 & 1,225 & 1,225 & 1,225 & 1,225 & 1,224 & 1,224 & 1,125 & 1,125 \\
\hline
\end{tabular}

Panel C: Less external finance dependent industries

\begin{tabular}{|c|c|c|c|c|c|c|c|c|c|c|}
\hline \multirow[b]{3}{*}{ Explanatory variable: } & \multicolumn{10}{|c|}{ Dependent variable: } \\
\hline & \multicolumn{2}{|c|}{ Change in Total Assets } & \multicolumn{2}{|c|}{$\begin{array}{c}\text { Change in Non-Cash } \\
\text { Assets }\end{array}$} & \multicolumn{2}{|c|}{$\begin{array}{l}\text { Change in Cash } \\
\text { Holdings }\end{array}$} & \multicolumn{2}{|c|}{ Dividends } & \multicolumn{2}{|c|}{ Total Payout } \\
\hline & (1) & (2) & (3) & (4) & (5) & (6) & (7) & (8) & (9) & (10) \\
\hline$I$ (Euro Country) x I(Post-Euro) & $\begin{array}{c}0.029 \\
(0.021)\end{array}$ & & $\begin{array}{c}0.027 \\
(0.021)\end{array}$ & & $\begin{array}{c}0.001 \\
(0.002)\end{array}$ & & $\begin{array}{c}0.003 \\
(0.003)\end{array}$ & & $\begin{array}{c}0.001 \\
(0.004)\end{array}$ & \\
\hline I(Strong Euro Country) x I(Post-Euro) & & $\begin{array}{c}0.017 \\
(0.020)\end{array}$ & & $\begin{array}{c}0.017 \\
(0.020)\end{array}$ & & $\begin{array}{c}0.000 \\
(0.002)\end{array}$ & & $\begin{array}{c}0.002 \\
(0.003)\end{array}$ & & $\begin{array}{l}-0.000 \\
(0.004)\end{array}$ \\
\hline$I$ (Weak Euro Country) x I(Post-Euro) & & $\begin{array}{l}0.054 * * \\
(0.024)\end{array}$ & & $\begin{array}{c}0.050^{* *} \\
(0.022)\end{array}$ & & $\begin{array}{c}0.003 \\
(0.004)\end{array}$ & & $\begin{array}{c}0.005 \\
(0.004)\end{array}$ & & $\begin{array}{c}0.003 \\
(0.006)\end{array}$ \\
\hline Control Variables & YES & YES & YES & YES & YES & YES & YES & YES & YES & YES \\
\hline Year Dummies and Fixed Firm Effects & YES & YES & YES & YES & YES & YES & YES & YES & YES & YES \\
\hline $\mathrm{R}^{2}$ & 0.31 & 0.31 & 0.30 & 0.30 & 0.10 & 0.10 & 0.64 & 0.64 & 0.54 & 0.54 \\
\hline Number of Firm-Year Observations & 15,358 & 15,358 & 15,328 & 15,328 & 15,328 & 15,328 & 15,056 & 15,056 & 12,053 & 12,053 \\
\hline Number of Firms & 1,254 & 1,254 & 1,252 & 1,252 & 1,252 & 1,252 & 1,248 & 1,248 & 1,125 & 1,125 \\
\hline
\end{tabular}


Table 9 (continued)

Panel D: Early versus later time period effects

\begin{tabular}{|c|c|c|c|c|c|c|c|c|c|c|}
\hline \multirow[b]{3}{*}{ Explanatory variable: } & \multicolumn{10}{|c|}{ Dependent variable: } \\
\hline & \multicolumn{2}{|c|}{ Change in Total Assets } & \multicolumn{2}{|c|}{$\begin{array}{c}\text { Change in Non-Cash } \\
\text { Assets }\end{array}$} & \multicolumn{2}{|c|}{$\begin{array}{l}\text { Change in Cash } \\
\text { Holdings }\end{array}$} & \multicolumn{2}{|c|}{ Dividends } & \multicolumn{2}{|c|}{ Total Payout } \\
\hline & $(1)$ & $(2)$ & (3) & $(4)$ & (5) & $(6)$ & (7) & $(8)$ & (9) & $(10)$ \\
\hline$I$ (Euro Country) x I(1999-2002) & $\begin{array}{c}0.011 \\
(0.018)\end{array}$ & & $\begin{array}{c}0.011 \\
(0.018)\end{array}$ & & $\begin{array}{c}0.000 \\
(0.003)\end{array}$ & & $\begin{array}{c}0.002 \\
(0.002)\end{array}$ & & $\begin{array}{c}0.000 \\
(0.003)\end{array}$ & \\
\hline$I($ Euro Country) x I(2003-2006) & $\begin{array}{l}0.075^{* *} \\
(0.027)\end{array}$ & & $\begin{array}{c}0.078^{* * *} \\
(0.024)\end{array}$ & & $\begin{array}{l}-0.001 \\
(0.004)\end{array}$ & & $\begin{array}{c}0.004 \\
(0.004)\end{array}$ & & $\begin{array}{c}0.002 \\
(0.006)\end{array}$ & \\
\hline I(Strong Euro Country) x I(1999-2002) & & $\begin{array}{l}-0.002 \\
(0.017)\end{array}$ & & $\begin{array}{l}-0.002 \\
(0.018)\end{array}$ & & $\begin{array}{l}-0.001 \\
(0.003)\end{array}$ & & $\begin{array}{c}0.001 \\
(0.002)\end{array}$ & & $\begin{array}{l}-0.000 \\
(0.002)\end{array}$ \\
\hline$I$ (Strong Euro Country) x I(2003-2006) & & $\begin{array}{c}0.061^{* *} \\
(0.025)\end{array}$ & & $\begin{array}{c}0.065^{* * *} \\
(0.022)\end{array}$ & & $\begin{array}{l}-0.002 \\
(0.004)\end{array}$ & & $\begin{array}{c}0.002 \\
(0.003)\end{array}$ & & $\begin{array}{l}-0.001 \\
(0.005)\end{array}$ \\
\hline$I($ Weak Euro Country) x I(1999-2002) & & $\begin{array}{l}0.045^{*} \\
(0.022)\end{array}$ & & $\begin{array}{l}0.043^{* *} \\
(0.019)\end{array}$ & & $\begin{array}{c}0.002 \\
(0.005)\end{array}$ & & $\begin{array}{c}0.003 \\
(0.003)\end{array}$ & & $\begin{array}{c}0.001 \\
(0.003)\end{array}$ \\
\hline$I($ Weak Euro Country) x I(2003-2006) & & $\begin{array}{c}0.108 * * * \\
(0.033)\end{array}$ & & $\begin{array}{c}0.108 * * * \\
(0.028)\end{array}$ & & $\begin{array}{c}0.001 \\
(0.004)\end{array}$ & & $\begin{array}{c}0.008 \\
(0.007)\end{array}$ & & $\begin{array}{c}0.006 \\
(0.009)\end{array}$ \\
\hline Control Variables & YES & YES & YES & YES & YES & YES & YES & YES & YES & YES \\
\hline Year Dummies and Fixed Firm Effects & YES & YES & YES & YES & YES & YES & YES & YES & YES & YES \\
\hline$\overline{\mathrm{R}^{2}}$ & 0.30 & 0.30 & 0.30 & 0.30 & 0.10 & 0.10 & 0.66 & 0.66 & 0.56 & 0.56 \\
\hline Number of Firm-Year Observations & 29,932 & 29,932 & 29,809 & 29,809 & 29,809 & 29,809 & 29,357 & 29,357 & 23,901 & 23,901 \\
\hline Number of Firms & 2,486 & 2,486 & 2,477 & 2,477 & 2,477 & 2,477 & 2,472 & 2,472 & 2,276 & 2,276 \\
\hline
\end{tabular}

